\title{
Plants Producing Ribosome-Inactivating Proteins in Traditional Medicine
}

\author{
Letizia Polito ${ }^{\dagger}$, Massimo Bortolotti ${ }^{\dagger}$, Stefania Maiello, Maria Giulia Battelli ${ }^{*}$ and \\ Andrea Bolognesi
}

\author{
Department of Experimental, Diagnostic and Specialty Medicine-DIMES, Alma Mater Studiorum, \\ University of Bologna, Via San Giacomo 14, 40126 Bologna, Italy; letizia.polito@unibo.it (L.P.); \\ massimo.bortolotti2@unibo.it (M.B.); stefania.maiello2@unibo.it (S.M.); andrea.bolognesi@unibo.it (A.B.) \\ * Correspondence: mariagiulia.battelli@unibo.it; Tel.: +39-051-209-4700; Fax: +39-051-209-4746 \\ † These authors contributed equally to this work. \\ Academic Editor: Els Van Damme \\ Received: 3 October 2016; Accepted: 9 November 2016; Published: 18 November 2016
}

\begin{abstract}
Ribosome-inactivating proteins (RIPs) are enzymes that deadenylate nucleic acids and are broadly distributed in the plant kingdom. Many plants that contain RIPs are listed in the pharmacopoeias of folk medicine all over the world, mostly because of their toxicity. This review analyses the position occupied in traditional medicine by plants from which RIPs have been isolated. The overview starts from the antique age of the Mediterranean area with ancient Egypt, followed by the Greek and Roman classic period. Then, the ancient oriental civilizations of China and India are evaluated. More recently, Unani medicine and European folk medicine are examined. Finally, the African and American folk medicines are taken into consideration. In conclusion, a list of RIP-expressing plants, which have been used in folk medicine, is provided with the geographical distribution and the prescriptions that are recommended by traditional healers. Some final considerations are provided on the present utilization of such herbal treatments, both in developing and developed countries, often in the absence of scientific validation. The most promising prospect for the medicinal use of RIP-expressing plants is the conjugation of purified RIPs to antibodies that recognise tumour antigens for cancer therapy.
\end{abstract}

Keywords: ribosome-inactivating proteins; plant toxins; anticancer drugs; folk medicine; ethnopharmacology; ancient Egypt medicine; classic age medicine; traditional Chinese medicine; Ayurveda medicine; Unani medicine

\section{Introduction}

Toxic substances, coming from either the mineral, vegetal or animal kingdom, have been frequently used for medical purposes since the earliest times. In particular, traditional medicine is based primarily on the use of plants, often taking advantage of those that are known for their toxicity, as a source of remedies for diseases that have always plagued humankind throughout the world. In addition, the knowledge of adverse events that arise from the consumption of some part of such toxic plants has its roots in very ancient time periods.

This review is dedicated to the role in traditional medicine played by plants from which ribosome-inactivating proteins (RIPs) have been extracted. RIPs are enzymes that depurinate nucleic acids and are widely distributed in the plant kingdom and beyond, whose biological role is yet to be elucidated. RIPs can be divided into two main categories: type 1, consisting of a single enzymatically active polypeptide, and type 2, consisting of a polypeptide that is similar to the type 1 RIP and has a lectin chain that is held together by a disulfide bridge (reviewed in [1]). 
Table 1. Ethno-pharmacological uses of RIP-expressing plants.

\begin{tabular}{|c|c|c|c|c|}
\hline $\begin{array}{l}\text { Plant Species, (Common Name), } \\
\text { Family and RIP Found }\end{array}$ & Geographic Area & Therapeutic Application & Plant Tissue(s) & References \\
\hline \multirow{2}{*}{$\begin{array}{l}\text { Abelmoschus esculentus (L.) Moench (okra) } \\
\text { Malvaceae } \\
\text { abelesculin }\end{array}$} & Africa & $\begin{array}{l}\text { Used as nervine, stomachic stimulant } \\
\text { Used for the treatment of gastritis, spasms }\end{array}$ & Fruits, seeds & {$[2,3]$} \\
\hline & India & Used for the treatment of anaemia, cancer, diabetes, gastric ulcer, gonorrhoea, urethrorrhoea & Fruits & [4-6] \\
\hline \multirow{3}{*}{$\begin{array}{l}\text { Abrus precatorius L. (jequirity) } \\
\text { Fabaceae } \\
\text { abrins }\end{array}$} & Africa & $\begin{array}{l}\text { Used for the treatment of asthma, bronchitis, cold, complaints, convulsion, cough, epilepsy, fever, } \\
\text { malaria, sexual asthenia, stomach cramps, tetanus, tuberculosis, urinary schistosomiasis, wounds }\end{array}$ & Leaves, roots, stems & [7-12] \\
\hline & India, Southeast Asia & $\begin{array}{l}\text { Used as abortifacient, analgesic, anthelminthic, anti-bacterial, anti-emetic, anti-pruritic, aphrodisiac, } \\
\text { expectorant, hair growth-promoting, purgative, tonic } \\
\text { Used for the treatment of amenorrhea, cancer, conjunctivitis, diabetes, diarrhoea, female fertility, } \\
\text { fever, inflammation, intestinal problems, leucorrhoea, malaria, menstrual disorders, migraine, } \\
\text { muscular skeletal disorders, postpartum complications, spasms, tetanus, urticaria }\end{array}$ & $\begin{array}{l}\text { Fruits, leaves, } \\
\text { roots, seeds }\end{array}$ & {$[9,13-17]$} \\
\hline & Caribbean & Used for the treatment of cold, consumption, cough, fever & Leaves & {$[18,19]$} \\
\hline $\begin{array}{l}\text { Adenia digitata (Harv.) Engl. } \\
\text { (modecca flower) } \\
\text { Passifloraceae } \\
\text { modeccins }\end{array}$ & South Africa & Used for the treatment of knee swellings, leprosy, skin ailment, swollen legs, ulcers & Roots & [20] \\
\hline $\begin{array}{l}\text { Adenia volkensii Harms (kilyambiti plant) } \\
\text { Passifloraceae } \\
\text { volkensin }\end{array}$ & Africa & $\begin{array}{l}\text { Used for the treatment of bronchitis, coughs, colds, fever, pneumonia, purgative, } \\
\text { stomach ache, swelling }\end{array}$ & Leaves, rootstock & [20] \\
\hline $\begin{array}{l}\text { Agrostemma githago L. (corncockle) } \\
\text { Caryophyllaceae } \\
\text { agrostins }\end{array}$ & Mediterranean area & Used for the treatment of skin outgrowths (warts, tumours) & Seeds & [21] \\
\hline $\begin{array}{l}\text { Amaranthus viridis L. (amarant) } \\
\text { Amaranthaceae } \\
\text { amaranthin }\end{array}$ & India, Pakistan & $\begin{array}{l}\text { Used as diuretic, laxative } \\
\text { Used for the treatment of dysentery, inflammation, scorpion sting, snakebites }\end{array}$ & $\begin{array}{l}\text { Leaves, roots, } \\
\text { whole plant }\end{array}$ & [22] \\
\hline $\begin{array}{l}\text { Aralia elata (Miq.) Seem. } \\
\text { (japanese angelica-tree) } \\
\text { Araliaceae } \\
\text { aralin }\end{array}$ & $\begin{array}{l}\text { China, India, Japan, } \\
\text { Korea, Russia }\end{array}$ & $\begin{array}{l}\text { Used as anti-arrhythmic, tonic } \\
\text { Used for the treatment of arthritis, diabetes, gastritis, gastrospasm, hepatitis, } \\
\text { hypertension, neurasthenia }\end{array}$ & Whole plant & [23-27] \\
\hline \multirow{2}{*}{$\begin{array}{l}\text { Asparagus officinalis L. (asparagus) } \\
\text { Asparagaceae } \\
\text { asparins }\end{array}$} & $\begin{array}{l}\text { China, India, } \\
\text { Japan, Korea }\end{array}$ & $\begin{array}{l}\text { Used as emmenagogue } \\
\text { Used for the treatment of arthralgia, diabetes, headache, urinary stones }\end{array}$ & Flowers, leaves, seeds & {$[4,23]$} \\
\hline & Mediterranean area & Used for the treatment of jaundice, sciatica, urinary and kidney dysfunctions & Roots & [21] \\
\hline \multirow{2}{*}{$\begin{array}{l}\text { Benincasa hispida (Thunb.) } \\
\text { Cogn. (winter melon) } \\
\text { Cucurbitaceae } \\
\text { benincasins, hispin }\end{array}$} & China, Korea & $\begin{array}{l}\text { Used as abortifacient, diuretic, emmenagogue, laxative, mucolytic } \\
\text { Used for the treatment of dehydration caused by fever or great heat, diabetes, dropsy, } \\
\text { hypertension, inflammation, liver and intestinal diseases, retention of placenta }\end{array}$ & $\begin{array}{l}\text { Fruits, roots, seeds, } \\
\text { whole plant }\end{array}$ & [28-31] \\
\hline & India & Used for the treatment of diabetes, nervous diseases, peptic ulcers, urinary disorders & Fruits, roots & {$[4,23]$} \\
\hline
\end{tabular}


Table 1. Cont

\begin{tabular}{|c|c|c|c|c|}
\hline $\begin{array}{l}\text { Plant Species, (Common Name), } \\
\text { Family and RIP Found }\end{array}$ & Geographic Area & Therapeutic Application & Plant Tissue(s) & References \\
\hline \multirow{3}{*}{$\begin{array}{l}\text { Beta vulgaris } \mathrm{L} \text {. (beet) } \\
\text { Amaranthaceae } \\
\text { beetins, betavulgin }\end{array}$} & Turkey & $\begin{array}{l}\text { Used as diuretic } \\
\text { Used for the treatment of diabetes, malaria }\end{array}$ & Leaves & {$[32,33]$} \\
\hline & Jordan & Used for the treatment of inflammation & Leaves, roots & [34] \\
\hline & Mediterranean area & Used as aphrodisiac, laxative & Leaves, roots & {$[21,35,36]$} \\
\hline \multirow{2}{*}{$\begin{array}{l}\text { Bryonia dioica Jacq. (bryony) } \\
\text { Cucurbitaceae } \\
\text { bryodins }\end{array}$} & Ancient Egypt & Used for the treatment of polyuria & Roots & [37-39] \\
\hline & Mediterranean area & Used as detoxifying, laxative & Fruits & {$[21,35,36]$} \\
\hline \multirow{2}{*}{$\begin{array}{l}\text { Celosia argentea L. (cockscomb) } \\
\text { Amaranthaceae } \\
\text { CCPs }\end{array}$} & India & $\begin{array}{l}\text { Used as anti-bacterial, aphrodisiac, diuretic } \\
\text { Used for the treatment of cancer, diabetes, eruptions, fever, gonorrhoea, healing of wounds, } \\
\text { inflammation, injuries, jaundice, metrorrhagia, mouth ulcers, skin sores, spasms, ulcers }\end{array}$ & Leaves, seeds & {$[4,40,41]$} \\
\hline & China & $\begin{array}{l}\text { Used as ailment for eyes and liver, disinfectant } \\
\text { Used for the treatment of blood diseases, broken bones, dysentery, dysuria, haematological and } \\
\text { gynaecologic disorders, inflammation, mouth sore }\end{array}$ & $\begin{array}{l}\text { Inflorescences, } \\
\text { leaves, seeds }\end{array}$ & {$[42,43]$} \\
\hline \multirow{2}{*}{$\begin{array}{l}\text { Chenopodium album L. (lamb's quarters) } \\
\text { Amaranthaceae } \\
\text { CAP30 }\end{array}$} & Africa & Used as anti-helminthic & Leaves, stems & {$[44]$} \\
\hline & India, Pakistan & Used as anti-parasitic, diuretic, hepato-protective, laxative, sedative & Whole plant & {$[45]$} \\
\hline \multirow{2}{*}{$\begin{array}{l}\text { Cinnamomum camphora (L.) J. Presl } \\
\text { (camphorwood) } \\
\text { Lauraceae } \\
\text { camphorins, cinnamomins }\end{array}$} & Persia & $\begin{array}{l}\text { Used as anti-septic, suppressor of sexual behaviours } \\
\text { Used for the treatment of boils, cold, sores, toothache }\end{array}$ & Seeds & {$[46,47]$} \\
\hline & China, Korea & $\begin{array}{l}\text { Used for the treatment of asthma, boils, bronchitis, chills, colds, diarrhoea, hysteria, indigestion, } \\
\text { muscle pains, nervousness, neuralgia, rheumatism, sores, sprains, toothache }\end{array}$ & Not indicated & {$[46,48]$} \\
\hline $\begin{array}{l}\text { Cinnamomum porrectum (Roxb.) Kosterm. } \\
\text { (yellow camphor) } \\
\text { Lauraceae } \\
\text { porrectin }\end{array}$ & Malaysia & Used for the treatment of wound infections & $\begin{array}{l}\text { Leaves, stem bark, } \\
\text { stem wood }\end{array}$ & [49] \\
\hline \multirow{5}{*}{$\begin{array}{l}\text { Citrullus colocynthis (L.) Schrad (colocynth) } \\
\text { Cucurbitaceae } \\
\text { colocins }\end{array}$} & Iran, Jordan & $\begin{array}{l}\text { Used as abortifacient, analgesic, anti-parasitic, cathartic, diuretic, hair growth-promoting, purgative } \\
\text { Used for the treatment of arthritis, diabetes, epilepsy, infections, inflammation, rheumatism }\end{array}$ & Fruits, roots, seeds & {$[22,50-52]$} \\
\hline & $\begin{array}{l}\text { India, Pakistan, } \\
\text { Sri Lanka }\end{array}$ & $\begin{array}{l}\text { Used as anti-bacterial, laxative } \\
\text { Used for the treatment of abdominal worms, cancer, diabetes, gas troubles, gastroenteritis, liver and } \\
\text { respiratory diseases, toothache, tuberculosis }\end{array}$ & Fruits, roots & {$[22,53-55]$} \\
\hline & $\begin{array}{l}\text { Africa, China, } \\
\text { Middle East }\end{array}$ & $\begin{array}{l}\text { Used as abortifacient, analgesic, anthelminthic, anti-bacterial, anti-oxidant, carminative, } \\
\text { emmenagogue, immunostimulator, laxative, mucolytic } \\
\text { Used for the treatment of cancer, cold, colic pain, cough, dehydration caused by fever or great heat, } \\
\text { diabetes, dysentery, gastroenteritis, gynaecological-, respiratory-, skin- and urinary infections, } \\
\text { hypertension, indigestion, inflammation, retention of placenta, sore throat, syphilis, } \\
\text { toothache, tuberculosis }\end{array}$ & Fruits, roots, seeds & {$[28,29,53,56-58$} \\
\hline & Ancient Egypt & Used as abortifacient, anthelmintic, cathartic, emmenagogue & Fruits & [37-39] \\
\hline & Mediterranean area & Used as detoxifying, laxative & Fruits & {$[21,35,36]$} \\
\hline
\end{tabular}


Table 1. Cont

\begin{tabular}{|c|c|c|c|c|}
\hline $\begin{array}{l}\text { Plant Species, (Common Name), } \\
\text { Family and RIP Found }\end{array}$ & Geographic Area & Therapeutic Application & Plant Tissue(s) & References \\
\hline $\begin{array}{l}\text { Clerodendrum inerme (L.) Schltdl. } \\
\text { (garden quinine) } \\
\text { Lamiaceae } \\
\text { CIPs }\end{array}$ & $\begin{array}{l}\text { Australia, China, India, } \\
\text { Southeast Asia }\end{array}$ & $\begin{array}{l}\text { Used as anti-fungal, hepato-protective } \\
\text { Used for the treatment of inflammation, cancer, fever, pain, skin diseases, viral infections }\end{array}$ & Leaves & {$[59,60]$} \\
\hline $\begin{array}{l}\text { Croton tiglium } \text { L. (purging croton) } \\
\text { Euphorbiaceae } \\
\text { crotins }\end{array}$ & China & $\begin{array}{l}\text { Used as laxative } \\
\text { Used for the treatment of abdominal pain, ascites, intestinal inflammation, oedema, peptic ulcer }\end{array}$ & Fruits, seeds & {$[46,61]$} \\
\hline $\begin{array}{l}\text { Cucurbita maxima Duchesne (autumn squash) } \\
\text { Cucurbitaceae } \\
\text { cucurmoschin }\end{array}$ & Caribbean & Used for the treatment of prostate problems & Fruits & [62] \\
\hline \multirow{2}{*}{$\begin{array}{l}\text { Cucurbita pepo L. (pumpkin) } \\
\text { Cucurbitaceae } \\
\text { pepocin }\end{array}$} & Caribbean, Iran & $\begin{array}{l}\text { Used for the treatment of enlarged prostate gland, irritable bladder, measles, peptic ulcer, small pox, } \\
\text { sprains, worm infections }\end{array}$ & Flowers, fruits, seeds & {$[18,62,63]$} \\
\hline & Mediterranean area & Used for the treatment of enlarged prostate gland, swelling & Fruits & {$[21,64]$} \\
\hline $\begin{array}{l}\text { Gynostemma pentaphyllum (Thunb.) } \\
\text { Makino (jiaogulan) } \\
\text { Cucurbitaceae } \\
\text { gynostemmin }\end{array}$ & China & $\begin{array}{l}\text { Used as abortifacient, anti-microbial, anti-proliferative, emmenagogue, immune-stimulator, regulator } \\
\text { of liver functions, laxative, mucolytic } \\
\text { Used for the treatment of cancer, cardiovascular and renal diseases, dehydration caused by fever or } \\
\text { great heat, diabetes, hyperlipoproteinemia, hypercholesterolemia, inflammation, } \\
\text { retention of placenta }\end{array}$ & Fruits, leaves, roots & {$[23,28,29,65-69]$} \\
\hline $\begin{array}{l}\text { Gypsophila elegans M.Bieb. } \\
\text { (annual baby's breath) } \\
\text { Caryophyllaceae } \\
\text { gypsophilin }\end{array}$ & China, India & Used for the treatment of immune disorders, liver diseases & Not indicated & [70] \\
\hline \multirow{3}{*}{$\begin{array}{l}\text { Hordeum vulgare L. (barley) Poaceae } \\
\text { JIP60, barley toxins }\end{array}$} & $\begin{array}{l}\text { China, India, } \\
\text { Japan, Korea }\end{array}$ & Used for the treatment of cardiovascular diseases, diabetes, hyperuricemia, urinary stones & Seeds & {$[23,54,71]$} \\
\hline & Ancient Egypt & Used as astringent and for the treatment of skin irritation & Seeds & [37-39] \\
\hline & Mediterranean area & $\begin{array}{l}\text { Used as tonic } \\
\text { Used for the treatment of gastric ulcers, gynaecological disorders }\end{array}$ & Seeds & {$[21,35,36]$} \\
\hline $\begin{array}{l}\text { Hura crepitans L. (sandbox tree) } \\
\text { Euphorbiaceae } \\
\text { H. crepitans RIPs, crepitin, hurin }\end{array}$ & South America & $\begin{array}{l}\text { Used as antidote for snakebites, emetic, purgative } \\
\text { Used for the treatment of elephantiasis, leprosy, rheumatism, toothache }\end{array}$ & Bark, latex, seeds & [72] \\
\hline \multirow[t]{2}{*}{$\begin{array}{l}\text { Jatropha curcas L. (purging nut) } \\
\text { Euphorbiaceae } \\
\text { curcins, Jc-SCRIP }\end{array}$} & Africa & $\begin{array}{l}\text { Used as purgative } \\
\text { Used for the treatment of dysentery, eczema, fever, gingivitis, guinea worm sores, infertility, } \\
\text { inflammation, jaundice, joint rheumatisms, miscarriage, mouth infections, skin parasites, } \\
\text { syphilis, toothache }\end{array}$ & $\begin{array}{l}\text { Bark, latex, leaves, } \\
\text { roots, seeds, stems }\end{array}$ & {$[73,74]$} \\
\hline & South America & $\begin{array}{l}\text { Used for the treatment of diarrhoea, external wounds, fever, heat, leishmaniasis, rashes, } \\
\text { sores, sprains }\end{array}$ & $\begin{array}{l}\text { Bark, fruits, latex, } \\
\text { leaves, roots }\end{array}$ & {$[18,75,76]$} \\
\hline \multirow{3}{*}{$\begin{array}{l}\text { Lagenaria siceraria (Molina) Standl. } \\
\text { (bottle gourd) } \\
\text { Cucurbitaceae } \\
\text { lagenin }\end{array}$} & India & $\begin{array}{l}\text { Used as aphrodisiac, antidote, diuretic, tonic } \\
\text { Used for the treatment of asthma, bronchial disorders, cough, diabetes, fever, hypertension, } \\
\text { liver diseases, pain, ulcers, weight loss }\end{array}$ & Fruits & [77-79] \\
\hline & Turkey & Used for the treatment of headache & Leaves & [80] \\
\hline & Mediterranean area & Used as detoxifying, laxative & Fruits & {$[21,35,36]$} \\
\hline
\end{tabular}


Table 1. Cont

\begin{tabular}{|c|c|c|c|c|}
\hline $\begin{array}{l}\text { Plant Species, (Common Name), } \\
\text { Family and RIP Found }\end{array}$ & Geographic Area & Therapeutic Application & Plant Tissue(s) & References \\
\hline $\begin{array}{l}\text { Luffa acutangula (L.) Roxb. (ridged luffa) } \\
\text { Cucurbitaceae } \\
\text { luffaculins, luffangulin }\end{array}$ & India & Used for the treatment of diabetes & Fruits & {$[54]$} \\
\hline $\begin{array}{l}\text { Luffa cylindrica (L.) M.Roem (sponge gourd) } \\
\text { Cucurbitaceae } \\
\text { LRIP, luffins, luffacylin }\end{array}$ & India, Korea & Used for the treatment of diabetes, fever, haemorrhage, phlegm & Fruits & {$[54,81]$} \\
\hline \multirow{4}{*}{$\begin{array}{l}\text { Manihot esculenta Crantz. (tapioca) } \\
\text { Euphorbiaceae } \\
\text { manutins }\end{array}$} & Africa & $\begin{array}{l}\text { Used as abortifacient, emmenagogue } \\
\text { Used for the treatment of anaemia }\end{array}$ & Leaves, stalks & {$[82,83]$} \\
\hline & Nicaragua & Used for the treatment of belly pain, diarrhoea, fever, headache, hypertension & \multirow{3}{*}{ Leaves } & \multirow{3}{*}{ [84] } \\
\hline & Papua New Guinea & Used for the treatment of skin blemishes & & \\
\hline & Colombia, Peru & Used for the treatment of worm infections, wounds & & \\
\hline $\begin{array}{l}\text { Mirabilis jalapa L. (four o'clock flower) } \\
\text { Nyctaginaceae } \\
\text { MAPs }\end{array}$ & Brazil, India, Mexico & $\begin{array}{l}\text { Used as diuretic, laxative, tonic } \\
\text { Used for the treatment of abscess, boils, bruises, diarrhoea, inflammation, pain, piles, ulcers, } \\
\text { urticaria, wounds }\end{array}$ & Leaves, stems & {$[85-87]$} \\
\hline \multirow{4}{*}{$\begin{array}{l}\text { Momordica balsamina L. (balsam) Cucurbitaceae } \\
\text { balsamin, MbRIP-1, momordin II }\end{array}$} & Africa & $\begin{array}{l}\text { Used as anthelminthic, purgative } \\
\text { Used for the treatment of arthritis, burns, chicken pox, diabetes, fever, gonorrhoea, inflammation, } \\
\text { jaundice, liver and skin diseases, malaria, measles, menorrhea, rheumatisms, scabies, skin allergies, } \\
\text { syphilis, ulcers }\end{array}$ & $\begin{array}{l}\text { Fruits, leaves, } \\
\text { roots, seeds }\end{array}$ & [88] \\
\hline & Pakistan & Used as wound healer & Leaves & [89] \\
\hline & India & Used for the treatment of diabetes & Not indicated & [54] \\
\hline & Mediterranean area & Used as detoxifying, laxative & Fruits & {$[21,35,36]$} \\
\hline \multirow{4}{*}{$\begin{array}{l}\text { Momordica charantia L. (bitter melon) } \\
\text { Cucurbitaceae } \\
\text { charantin, MAP 30, MCLs, momorcharins, } \\
\text { momordins }\end{array}$} & $\begin{array}{l}\text { Africa, Central and } \\
\text { South America }\end{array}$ & $\begin{array}{l}\text { Used as anthelminthic } \\
\text { Used for the treatment of burns, chicken pox, diabetes, dysentery, fever, gonorrhoea, hypertension, } \\
\text { inflammation, jaundice, kidney and skin diseases, liver, malaria, measles, menorrhea, rheumatisms, } \\
\text { scabies, syphilis, ulcers, womb infection }\end{array}$ & Fruits, leaves, stems & {$[18,88,90-92]$} \\
\hline & India & $\begin{array}{l}\text { Used as abortifacient, anthelminthic, anti-mutagenic, anti-oxidants, emmenagogue, } \\
\text { galactagogue, laxative, } \\
\text { Used for the treatment of boils, burns, chronic fever, diabetes, dysmenorrhea, eczema, gout, jaundice, } \\
\text { joint pain, kidney stones, leprosy, leucorrhoea, liver and digestive disorders, malaria, piles, } \\
\text { pneumonia, psoriasis, rheumatism, snake poisoning }\end{array}$ & $\begin{array}{l}\text { Fruits, seeds, } \\
\text { roots, leaves }\end{array}$ & [93-95] \\
\hline & Thailand & $\begin{array}{l}\text { Used as anthelminthic, anti-oxidant, anti-pyretic, blood tonic, carminative, cholagogue, } \\
\text { digestive, laxative }\end{array}$ & Fruits, leaves & [96] \\
\hline & Turkey & Used for the treatment of cuts, peptic ulcers, wounds & Fruits & {$[80,97,98]$} \\
\hline $\begin{array}{l}\text { Momordica cochinchinensis (Lour.) Spreng. } \\
\text { (red melon) } \\
\text { Cucurbitaceae } \\
\text { cochinin B, momorcochins }\end{array}$ & China & $\begin{array}{l}\text { Used as abortifacient, emmenagogue, laxative, mucolytic } \\
\text { Used for the treatment of dehydration caused by fever or great heat, diabetes, inflammation, } \\
\text { retention of placenta }\end{array}$ & Fruits, seeds & {$[23,28,29,99]$} \\
\hline
\end{tabular}


Table 1. Cont

\begin{tabular}{|c|c|c|c|c|}
\hline $\begin{array}{l}\text { Plant Species, (Common Name), } \\
\text { Family and RIP Found }\end{array}$ & Geographic Area & Therapeutic Application & Plant Tissue(s) & References \\
\hline \multirow{3}{*}{$\begin{array}{l}\text { Oryza sativa L. (rice) } \\
\text { Poaceae } \\
\text { oryza sativa RIP }\end{array}$} & India & Used for the treatment of diabetes, leucorrhoea & Seeds & {$[54,100]$} \\
\hline & $\begin{array}{l}\text { Palestine, Iran, } \\
\text { Mediterranean area }\end{array}$ & Used for the treatment of diarrhoea, peptic ulcer & Fruits & {$[21,63,100]$} \\
\hline & Thailand & Used for the treatment of wound healing & Not indicated & [101] \\
\hline $\begin{array}{l}\text { Panax ginseng C.A.Mey (Chinese ginseng) } \\
\text { Araliaceae } \\
\text { panaxagin }\end{array}$ & $\begin{array}{l}\text { China, India, Japan, } \\
\text { Korea }\end{array}$ & $\begin{array}{l}\text { Used as prophylactic, restorative, tonic } \\
\text { Used for the treatment of anorexia, diabetes, haemorrhage, hypodynamia, impotence, insomnia, } \\
\text { palpitation, shortness of breath }\end{array}$ & $\begin{array}{l}\text { Berries, leaves, } \\
\text { rhizomes, roots }\end{array}$ & {$[23,102-104]$} \\
\hline $\begin{array}{l}\text { Panax quinquefolium L. (American ginseng) } \\
\text { Araliaceae } \\
\text { quinqueginsin }\end{array}$ & $\begin{array}{l}\text { China, India, } \\
\text { Japan, Korea }\end{array}$ & Used for the treatment of cancer, diabetes, inflammation, metabolic syndrome & Roots & {$[23,104,105]$} \\
\hline $\begin{array}{l}\text { Phytolacca acinosa Roxb (Indian poke) } \\
\text { Phytolaccaceae } \\
\text { PAP-S1aci }\end{array}$ & China & Used for the treatment of anasarca, ascites, constipation, reduction of swelling and nodules & Roots & [46] \\
\hline $\begin{array}{l}\text { Phytolacca americana L. (pokeweed) } \\
\text { Phytolaccaceae } \\
\text { PAPs }\end{array}$ & $\begin{array}{l}\text { Africa, China, Japan, } \\
\text { Korea }\end{array}$ & $\begin{array}{l}\text { Used as laxative } \\
\text { Used for the treatment of ascites, fibroids growth, lymphatic congestion, mastitis, oedema, reduction } \\
\text { of swelling and nodules, rheumatism, swellings, wound }\end{array}$ & Fruits, leaves, roots & {$[46,106,107]$} \\
\hline $\begin{array}{l}\text { Phytolacca dodecandra L'Hér. } \\
\text { (African soapberry) } \\
\text { Phytolaccaceae } \\
\text { dodecandrins }\end{array}$ & Africa & $\begin{array}{l}\text { Used for the treatment of ascariasis, eczema, gonorrhoea, jaundice, malaria, rabies, rheumatic pain, } \\
\text { sore throat, syphilis pruritus, vitiligo }\end{array}$ & Fruits, roots & [108] \\
\hline \multirow{3}{*}{$\begin{array}{l}\text { Pisum sativum L. (pea) Fabaceae } \\
\text { pisavins }\end{array}$} & Pakistan & Used as anti-spermatogenic & Seeds & [89] \\
\hline & Africa & $\begin{array}{l}\text { Used as abortifacient, purgative } \\
\text { Used for the treatment of alopecia, arthritis, body ache, conjunctivitis, cutaneous lesions, dermatoses, } \\
\text { fractures, headache, mycosis, neuralgia, rheumatism, scabies, sprain }\end{array}$ & $\begin{array}{l}\text { Fruits, leaves, roots, } \\
\text { seeds, }\end{array}$ & {$[11,82,109-111]$} \\
\hline & Ancient Egypt & Used as astringent and for the treatment of skin irritation & Seeds & [37-39] \\
\hline \multirow{6}{*}{$\begin{array}{l}\text { Ricinus communis L. (castor bean) } \\
\text { Euphorbiaceae } \\
\text { ricins }\end{array}$} & Mediterranean area & $\begin{array}{l}\text { Used as aperient, detoxifying, emetic, galactogogue, laxative } \\
\text { Used for the treatment of phlegm, sunburn, varicose veins }\end{array}$ & Leaves, seeds & {$[21,35,36,112]$} \\
\hline & China, India, & $\begin{array}{l}\text { Used as anthelmintic, anti-bacterial, aphrodisiac, cathartic, laxative } \\
\text { Used for the treatment of anti-fertility, arthritic pain, cancer, chronic wounds, convulsions, diabetes, } \\
\text { epilepsy, fever, hair loss, inflammation, rhinitis, skin diseases, swelling, ulcers }\end{array}$ & $\begin{array}{l}\text { Latex, leaves, roots, } \\
\text { seeds, stem bark }\end{array}$ & [112-117] \\
\hline & Iran, Pakistan & $\begin{array}{l}\text { Used for the treatment of boils, chronic knee osteoarthritis, gout, liver diseases, rheumatism, } \\
\text { sores, wounds }\end{array}$ & Leaves, seeds & {$[22,118]$} \\
\hline & Caribbean, Brazil & $\begin{array}{l}\text { Used as anthelminthic, purgative } \\
\text { Used for the treatment of burn, erysipelas, flu, hair loss, stomach aches, womb inflammation, } \\
\text { wound healing }\end{array}$ & Leaves & {$[18,19]$} \\
\hline & Africa & $\begin{array}{l}\text { Used as abortifacient, tocolytic } \\
\text { Used for the treatment of alopecia, arthritis, conjunctivitis, cutaneous lesions, dermatoses, fracture, } \\
\text { inflammation, mycosis, neuralgia, rheumatism, scabies, sprain }\end{array}$ & Fruits, leaves, roots & {$[82,109,110]$} \\
\hline & Ancient Egypt & $\begin{array}{l}\text { Used as abortifacient, laxative } \\
\text { Used for the treatment of abscessual illness, baldness, polyuria }\end{array}$ & Fruits, roots & [37-39] \\
\hline
\end{tabular}


Table 1. Cont.

\begin{tabular}{|c|c|c|c|c|}
\hline $\begin{array}{l}\text { Plant Species, (Common Name), Family and } \\
\text { RIP Found }\end{array}$ & Geographic Area & Therapeutic Application & Plant Tissue(s) & References \\
\hline \multirow{2}{*}{$\begin{array}{l}\text { Sambucus ebulus L. (dwarf elder) } \\
\text { Adoxaceae } \\
\text { ebulins, ebulitins, SEA }\end{array}$} & Iran & $\begin{array}{l}\text { Used for the treatment of bee/nettle bites, bone/joint disorders, chronically inflammatory diseases, } \\
\text { eczema, fungal skin disorders, haemorrhoids }\end{array}$ & $\begin{array}{l}\text { Aerial parts, fruits, } \\
\text { leaves, rhizomes, roots }\end{array}$ & [119-122] \\
\hline & Turkey & Used for the treatment of cold, cough, knee ache, rheumatism pain, snakebites, urticaria, & $\begin{array}{l}\text { Flowers, fruits, leafy } \\
\text { stems, leaves, roots }\end{array}$ & {$[97,123]$} \\
\hline \multirow{4}{*}{$\begin{array}{l}\text { Sambucus nigra L. (elderberry) } \\
\text { Adoxaceae } \\
\text { nigrins, nigritins, SNAs, SNLRPs }\end{array}$} & Mediterranean area & $\begin{array}{l}\text { Used as diuretic, laxative } \\
\text { Used for the treatment of asthma, burns, cough, eye inflammation, haemorrhoids, pimples, throat } \\
\text { infections, scalds, wounds }\end{array}$ & $\begin{array}{l}\text { Bark, buds, flowers, } \\
\text { leaves, marrow, pith }\end{array}$ & [124] \\
\hline & North Europe & $\begin{array}{l}\text { Used as cathartic, diaphoretic in upper respiratory tract infections, diuretic, laxative } \\
\text { Used for the treatment of headache, low back or neuropathic pain, toothache }\end{array}$ & Fruits & [125] \\
\hline & East Europe & $\begin{array}{l}\text { Used as anti-septic, anti-catarrhal, diuretic, expectorant, sedative } \\
\text { Used for the treatment of arteriosclerosis, colds, fever, hypertension, inflammations, insomnia, } \\
\text { perspiration, nervous tachycardia }\end{array}$ & Flowers & {$[126,127]$} \\
\hline & Turkey & Used for the treatment of abscesses, asthma, bronchitis, haemorrhoids, prostatitis, rheumatisms & Flowers, fruits, leaves & {$[97,121,128]$} \\
\hline $\begin{array}{l}\text { Saponaria officinalis L. (soapwort) } \\
\text { Caryophyllaceae } \\
\text { saporins }\end{array}$ & Mediterranean area & Used as emmenagogue & Not indicated & {$[21,35,36]$} \\
\hline $\begin{array}{l}\text { Siraitia grosvenorii (Swingle) C. Jeffrey ex A.M. } \\
\text { Lu \& Zhi Y. Zhang (monk fruit) } \\
\text { Cucurbitaceae } \\
\text { momorgrosvin }\end{array}$ & $\begin{array}{l}\text { China, India, Japan, } \\
\text { Korea }\end{array}$ & $\begin{array}{l}\text { Used as abortifacient, emmenagogue, laxative, mucolytic } \\
\text { Used for the tratment of dehydration caused by fever or great heat, dire thirst, dry cough, } \\
\text { pharyngitis, retention of placenta, sore throat sweetener }\end{array}$ & Fruits, roots & {$[23,28,29,129-131]$} \\
\hline $\begin{array}{l}\text { Spinacia oleracea L. (spinach) } \\
\text { Amaranthaceae } \\
\text { SoRIPs }\end{array}$ & India, Turkey & Used as diuretic an for the treatment of diabetes & Aerial parts & {$[33,54]$} \\
\hline $\begin{array}{l}\text { Stellaria media (L.) Vill. (chickweed) } \\
\text { Caryophyllaceae } \\
\text { RIP Q3 }\end{array}$ & China, India & $\begin{array}{l}\text { Used for the treatment of arthritis, bronchitis, dermatitis, inflammation, mange, period and } \\
\text { rheumatic pains, skin diseases, viral infections }\end{array}$ & Whole plant & {$[129,132]$} \\
\hline $\begin{array}{l}\text { Trichosanthes cucumerina L. (snake gourd) } \\
\text { Cucurbitaceae } \\
\text { TCSL }\end{array}$ & $\begin{array}{l}\text { French Guiana, India, } \\
\text { Sri lanka, }\end{array}$ & $\begin{array}{l}\text { Used as anthelminthic, cathartic, hepato- and gastro-protector, hypoglycaemic, larvicidal } \\
\text { Used for the treatment of boils, bronchitis, cancer, dermatitis, diabetes, fever, eczema, headache, } \\
\text { indigestion, inflammation, liver congestion, ovulation, psoriasis, sores, stomach disorders, } \\
\text { urticaria, ulcers }\end{array}$ & Fruits, leaves, roots & {$[4,133-135]$} \\
\hline $\begin{array}{l}\text { Trichosanthes cucumeroides (Ser.) Maxim. } \\
\text { (Japanese snake gourd) } \\
\text { Cucurbitaceae } \\
\beta \text {-trichosanthin }\end{array}$ & China & $\begin{array}{l}\text { Used as abortifacient, emmenagogue, mucolytic } \\
\text { Used for the treatment of dehydration caused by fever or great heat, diabetes, retention of placenta }\end{array}$ & Fruits, root tubers & {$[23,136]$} \\
\hline $\begin{array}{l}\text { Trichosanthes kirilowii Maxim. } \\
\text { (Chinese snake gourd) } \\
\text { Cucurbitaceae } \\
\text { kirilowins, TAP 29, TK-35, trichobitacin, } \\
\text { trichokirins, trichomislin, trichosanthins, } \\
\text { trichosanthrip }\end{array}$ & China & $\begin{array}{l}\text { Used as abortifacient, emmenagogue, galactagogue, laxative, mucolytic } \\
\text { Used for the treatment of cancer, cough, dehydration caused by fever or great heat, diabetes, } \\
\text { gynaecological illnesses, hydatiform moles, invasive moles, retention of placenta }\end{array}$ & Fruits, root tubers & {$[17,23,28,29,137-139]$} \\
\hline
\end{tabular}


Table 1. Cont.

\begin{tabular}{|c|c|c|c|c|}
\hline $\begin{array}{l}\text { Plant Species, (Common Name), } \\
\text { Family and RIP Found }\end{array}$ & Geographic Area & Therapeutic Application & Plant Tissue(s) & References \\
\hline $\begin{array}{l}\text { Triticum aestivum L. (wheat) } \\
\text { Poaceae } \\
\text { tritins }\end{array}$ & $\begin{array}{l}\text { Ancient Egypt, India, } \\
\text { Mediterranean area }\end{array}$ & $\begin{array}{l}\text { Used as tonic } \\
\text { Used for the treatment of burns, gynaecological disorders leucorrhoea, skin lesions, sprains, } \\
\text { whitlows, wounds }\end{array}$ & Seeds & {$[16,21,35-39,124]$} \\
\hline \multirow{4}{*}{$\begin{array}{l}\text { Viscum album L. (mistletoe) } \\
\text { Santalaceae } \\
\text { mistletoe lectins }\end{array}$} & India & Used for the treatment of diabetes & Leaves & [140] \\
\hline & $\begin{array}{l}\text { Germany, } \\
\text { Mediterranean Europe }\end{array}$ & $\begin{array}{l}\text { Used as emetic } \\
\text { Used for the treatment of abscesses, cancer, chilblains, gynaecological disorders, scrofula, } \\
\text { spleen diseases }\end{array}$ & Not indicated & {$[124,141,142]$} \\
\hline & Africa & $\begin{array}{l}\text { Used for the treatment of asthma, bronchitis, cardio-vascular diseases, hypertension, painful } \\
\text { menstruation, stomach ailment, stroke, tumour swellings }\end{array}$ & Leaves, whole plant & {$[106,143,144]$} \\
\hline & Turkey & $\begin{array}{l}\text { Used for the treatment of asthma, atherosclerosis, brain cancer, breathing difficulties, bronchitis, } \\
\text { cardiovascular diseases, chronic cramps, diabetes, headache, heart palpitations, } \\
\text { hypercholesterolemia, hypertension, hypogalactia, prostatitis, rheumatism, splenopancreatic } \\
\text { diseases, sterility, stomach problems, stroke, tachycardia, throat ache, tonic, toothache, tonsillitis }\end{array}$ & $\begin{array}{l}\text { Fruits, leafy, leaves } \\
\text { branches, twigs }\end{array}$ & {$[97,145-148]$} \\
\hline \multirow[t]{2}{*}{$\begin{array}{l}\text { Ximenia americana L. (sea lemon) } \\
\text { Oleaceae } \\
\text { riproximins }\end{array}$} & Africa & $\begin{array}{l}\text { Used for the treatment of anaemia, arthritis, amenorrhea, anxiety, asthma, back and abdominal pain, } \\
\text { bleeding after menstruation, burns, candida infection, conjunctivitis, cough, dermatitis, diabetes, } \\
\text { dysentery, dysmenorrhoea, fever, food poisoning, gastric ulcer, gingivitis, headaches, haemorrhoids, } \\
\text { infertility, internal wounds, malaria, measles, mental diseases, migraine, otitis, schistosomiasis, } \\
\text { sinusitis, snake/scorpion bites, throat infections, tonic, tooth ache, urinary tract infections, uterine } \\
\text { cancer, uterine prolapse, vaginitis, varicose veins, vomiting, wounds }\end{array}$ & $\begin{array}{l}\text { Bark, fruits, leaves, } \\
\text { roots, seeds, stems }\end{array}$ & [149-151] \\
\hline & Brazil & $\begin{array}{l}\text { Used as laxative } \\
\text { Used for the treatment of cough, diabetes, hoarseness, inflammation, obesity, osteoporosis pain, } \\
\text { venereal disease, wound healing }\end{array}$ & Bark, fruits, roots & [19] \\
\hline \multirow{3}{*}{$\begin{array}{l}\text { Zea mays L. (corn) } \\
\text { Poaceae } \\
\text { b-32 }\end{array}$} & $\begin{array}{l}\text { China, India, Japan, } \\
\text { Korea, Middle Est }\end{array}$ & $\begin{array}{l}\text { Used as digestive } \\
\text { Used for the treatment of cancer, diabetes, different diseases (circulatory, connective tissue, } \\
\text { genitourinary, musculoskeletal, respiratory system) }\end{array}$ & Flowers & {$[23,152]$} \\
\hline & Africa & Used for the treatment of inflammation, pain & Husk & {$[153]$} \\
\hline & Peru & $\begin{array}{l}\text { Used as anti-oxidant, tonic } \\
\text { Used for the treatment of amenorrhea, dysentery, dysmenorrhea, flu, obesity, oliguria }\end{array}$ & Seeds & {$[18,154]$} \\
\hline
\end{tabular}


Some of the type 2 RIPs are highly toxic and for this reason have been recognized since ancient times by traditional healers, starting from Ricinus communis L. (castor bean), which produces ricin, the best known RIP and also one of the oldest known RIPs. A list of RIP-expressing plants, traditionally identified as medicinal plants for their pharmacological properties, is given in Table 1.

Plants that have historically been a source for traditional medical treatments have been recorded in documents that can be traced back over millennia to Western and Oriental ancient civilisations, starting from the Mesopotamian clay tablets in cuneiform (approximately 2600 BC). In other geographical areas, written documents are not available and the botanical knowledge that has been the foundation for the folk medicine is based on oral tradition.

\section{Ancient Egyptian Medicine}

A lot of information on the rich pharmacopoeia of ancient Egyptian civilization can be obtained from the papyri that were discovered in pyramids and tombs; hundreds of different compounds, many of which have not yet been identified, are described and recommended for several diseases. The identified products are minerals, vegetables and animals or human derivatives.

Castor bean seeds have been employed since ancient times for various purposes and have been found in Egyptian tombs that are approximately 6000 years old, probably because an oil can be extracted from the castor bean seeds and can be used as fuel for lighting lamps.

The pulp and oil of the castor bean fruit were utilized to prepare an ointment with medicinal or cosmetic purposes, as a remedy against abscessual illness or to favour hair growth, respectively. The first written record of these utilizations in ancient Egypt can be found in the "Ebers Papyrus", a medical treatise that dates back to approximately $1500 \mathrm{BC}$, although it is considered to be a collection of much older different manuscripts. The "Ebers Papyrus" has over 800 recipes and gives us the most information about drug preparations. In the papyrus, an important role was given to the castor bean plant, in fact an entire section is devoted to castor bean [37].

Castor bean and Bryonia dioica Jacq. (bryony) roots were ingredients of a concoction described in "Ebers Papyrus" for the correction of polyuria of a child perhaps affected by diabetes [38]. Castor bean was also prescribed as a drug for internal use due to laxative or abortifacient intents. The toxicity of castor bean was well known, and only small amounts of seeds were utilized to prepare drugs for oral ingestion. In most cases, castor bean-containing medicinal preparations were based on the nontoxic fat component of the kernels, which was used in formulations both for external use with the aim of healing or soothing the skin and for internal use with a laxative purpose as castor bean oil.

Another plant that was mentioned in different Egyptian papyri is Citrullus colocynthis L. (colocynth). The fruit of the colocynth showed strong cathartic properties when taken boiled in water. This preparation was also able to induce menses and was used as an abortifacient. Additionally, in the "Ebers Papyrus", a vaginal application of a colocynth-containing mixture was suggested to interrupt pregnancy. Moreover, the colocynth was reduced to powder and mixed with other ingredients to produce ointments for external use against parasitic worms.

In addition to castor bean, bryony and colocynth, other plants have been described in the "Ebers Papyrus" and in other Egyptian medical papyri because of their medical applications, possibly corresponding to Hordeum vulgare L. (barley), Lagenaria siceraria Stand. (bottle gourd), Pisum sativum L. (peas) and Triticum aestivum L. (wheat) [155], which are known to express RIPs ([156], reviewed in [157]). Barley, peas and wheat were prescribed for external application such as poultices against skin irritation and to obtain an astringent effect. The plants belonging to the Cucurbitaceae family were included in most preparations with plant ingredients probably due to their purgative action [155]. Barley was also used to detect pregnancy and to determine the sex of the foetus (reviewed in [158]).

The biblical plant kikaion, which is mentioned in the book of Jonah because it granted shadow to the prophet in the desert close to Ninive, was thought to correspond to the castor bean tree [159]. A great portion of the medical and botanical knowledge of the ancient Hebrew people, including the 
pharmacological properties of the plants, was possibly acquired during the period of permanence in Egypt [39].

\section{Classic Age Medicine}

Egyptian information about herbal medicine and drug preparation provided the base for the Greek and Roman pharmacopoeias, as confirmed in particular by Hippocrates (470-377 BC) in the "Hippocratic Corpus", Celsus (25 BC-50 AD) in the "De Medicina", Pedanius Dioscorides (40-80 AD) in the "De Materia Medica", Pliny the Elder (23-79 AD) in the "Natural History" and Galeno (129-200 $\mathrm{AD}$ ) in the "Galenic Corpus".

Many plants were described by Hippocrates, who is considered the father of Western medicine, for therapeutic use in several diseases. Among them, there were various RIP-producing plants, such as Momordica balsamina L. (balsam), barley, bottle gourd, bryony, colocynth, Sambucus nigra L. (elderberry), Viscum album L. (mistletoe), castor bean, Saponaria officinalis L. (soapwort) and wheat $[35,36]$.

Hippocrates prescribed the juice of the Cucurbitaceae or castor bean oil for laxative and detoxifying action, as well as soapwort pessaries to stimulate or increase menstrual flow, whereas barley could give strength and health. Wheat flour, sometimes as an alternative to barley, was an ingredient in gynaecological recipes for the preparation of tea and meal with the purpose of promoting fertility [36]. Elderberry was defined as "nature's medicine chest" by Hippocrates because of its health benefits in a variety of diseases, in particular as a diuretic and a laxative. Dioscorides first distinguished the elderberry from the dwarf elder (Sambucus ebulus L.), while recognizing that both plants exhibited the same medicinal properties. Today elderberry is still acknowledged for its properties against oxidative stress and its use is suggested for the treatment of influenza [126].

Mistletoe was recommended by Hippocrates as an emetic and for the treatment of spleen diseases and disorders associated with menstruation, whereas mistletoe-containing mixtures were recommended by Celsus for external use to treat abscesses, carcinoids, and scrofula. In a Celtic ritual ceremony mistletoe played a pivotal role because the Celtic druids believed that "it given in drink will pass on fertility to any animal that is sterile and that it is an antidote to all poisons", as described by Pliny the Elder in the "Natural History".

Dioscorides was a military physician and pharmacognosist of Nero's Army; he is considered the father of pharmacognosy. He described more than 600 drugs of plant origin. About the application of castor bean, he reported that "Thirty grains, cleaned, pounded into small pieces, and taken in a drink drives out phlegm, bile, and water through the bowels. They also induce vomiting, but this purging is harsh and extremely drastic, overturning the stomach excessively. Pounded and applied it cleans varicose veins and sunburn" [21]. Accordingly, Pliny recognized the therapeutic properties as an aperient, which was attributed by the Greeks to castor beans.

The purgative and cathartic nature of bryony was known to Dioscorides and was also later prescribed by Galeno. Pliny believed that eating barley was a valid remedy against gastric ulcers. Beta vulgaris L. (beet) was acknowledged by the Romans as a laxative and the beetroot juice as an aphrodisiac. Agrostemma githago L. (corncockle) has been used to cure skin outgrowths, such as warts and tumours. Cucurbita pepo L. (pumpkin) was mentioned by Hippocrates, Dioscorides, Pliny and Galeno as a remedy against swelling. Dioscorides recommended the use of extracts of Asparagus officinalis L. (asparagus) root for the treatment of jaundice, sciatica and urinary and kidney dysfunctions. About the Oryza sativa L. (rice), Dioscorides says that "it sustains poorly and tightens the belly". These antique manuscripts addressed the medical thinking of European physicians until the development of modern medicine, together with the oral traditions passed on by local folk medicine.

\section{Traditional Chinese Medicine}

The earliest Chinese pharmacopoeia has been attributed to Shennong, i.e., the Divine Farmer, a mythical ancestor of the Han population, who possibly lived in China in the third millennium $\mathrm{BC}$. He would have begun a prehistoric oral tradition about agriculture and medicinal plants that 
was recorded into a lost compilation written in the first century BC. The subject was reworked and amplified by Li Shizhen, a sixteenth-century Chinese doctor who wrote the "Compendium of Materia Medica", a medical treatise that included the classification of the herbs to be used as medications for treating diseases. The currently available text, "The Divine Farmer's Materia Medica" [28], is a result of a series of rearrangements carried out over the centuries. Traditional Chinese medicine includes among herbal drugs a number of plants that produce RIPs, as detailed in Table 1.

Fruits and roots of the Cucurbitaceae were used: (i) to treat dehydration that was caused by fever or great heat; (ii) for mucolytic action in individuals with respiratory infections; (iii) to resolve intestinal constipation due to dry stools; and (iv) to induce menstruation, the expulsion of a retained placenta and abortion ([28], reviewed in [29]). The latex of the castor bean plant was instilled in the ear of the patient to cure rhinitis, whereas the seeds were used for anthelmintic activity. For external use, a seed poultice or leaf juice was recommended to treat ulcers and chronic wounds (reviewed in [112]). Leaves, inflorescences and seeds of Celosia argentea L. (cockscomb) have been prescribed for internal use to cure haematological and gynaecologic disorders and for external use in the treatment of inflammation and as a disinfectant [42].

Phytolacca acinosa Roxb. (Indian poke) and Phytolacca americana L. (pokeweed) roots were given both for internal use, in the case of constipation to induce a laxative effect or as a diuretic in the case of anasarca and ascites, and for external use to reduce swelling and nodules. Both in Chinese and Unani traditional medicines, the Cinnamomum camphora L. (camphorwood) was utilized to alleviate pain, in particular toothache, and also as a source of a topical application to treat sores and boils, whereas the seeds of purging croton were indicated to reduce oedema and ascites (reviewed in [46]).

According to traditional medicine in China, India and other oriental countries, Clerodendrum inerme L. (garden quinine) has been used for the cure of inflammatory diseases, including arthritis and rheumatic pain, skin diseases and fever and for the treatment of cancer [59]. The fruits of the colocynth have been prescribed for the treatment of gastrointestinal diseases, respiratory infections, diabetes and cancer (reviewed in [53]). Fresh Stellaria media L. (chickweed) juice has been administered for the treatment of viral diseases and dermatitis [132]. A variety of plants that were used in traditional medicine in China, India, Japan and Korea to treat diabetes due to their anti-hyperglycaemic activity includes Trichosanthes cucumeroides Maxim. (Japanese angelica-tree), barley, Zea mays L. (corn), asparagus, Panax ginseng Meyer (Chinese ginseng), Panax quinquefolium L. (American ginseng) and a number of Cucurbitaceae (reviewed in [23]).

The folk medicine of other Southeast Asian countries exploits the pharmacological properties of the local flora; in Malaysia, the leaves, stem-bark and stem-wood of Cinnamomum porrectum (Roxb.) possess antibacterial activity and have been traditionally used to treat wound infections [49].

Folk herbal medicine is still diffused in a large proportion of the population, mostly in developing countries for cultural reasons, and exists side by side with modern medicine. This is true for traditional Chinese medicine in China and also in Japan where this system of traditional healing survives under the name of Kampo medicine and was first codified in the tenth century by Yasuyori Tamba in the "Ishimpo" [160].

\section{Ayurveda Medicine}

The oldest known Hindu text on life sciences and Ayurveda folk medicine is "Charaka Samhita or Compendium of Charaka" and was written in Sanskrit. Charaka, a physician who lived in the second century BC, reported the teachings of a tradition that dated back to $1000 \mathrm{BC}$ and was possibly based on the much more ancient Vedic wisdom. The current version of the manuscript, which was revised approximately 1600 years ago, discusses a variety of medical subjects. It also contains much botanical information and a series of instructions to prepare therapeutic formulations [161]. A number of RIP-expressing plants are included in such recipes in addition to the antidiabetic herbs and garden quinine, which were already mentioned in relation to traditional Chinese medicine, as described below. 
Different parts of Abrus precatorius L., commonly known as Indian liquorice or jequirity, have been used both in Ayurvedic and Tamil folk medicine, including the seeds, leaves and roots, to prepare oil, tea or concoctions. Traditional healers knew about the poisonous effects of the ingestion of the seeds; therefore, they followed various methods of purification to abolish or at least mitigate the toxicity, such as boiling the seeds in milk before they were administered to patients. The plant has been claimed to possess aphrodisiac and hair-growth promoting activities. It was used to treat urticaria, migraine, malaria, tetanus and conjunctivitis due to its anti-pruritic, analgesic, anti-pyretic, anti-spasmodic and anti-phlogistic properties, respectively. The use of jequirity was also recognized to produce therapeutic effects including anti-tumour, expectorant, purgative, anti-diabetic, abortifacient, anthelmintic and anti-bacterial effects, in particular against ulcers and wounds. After being boiled, the seeds can be safely eaten in a similar fashion as nutritious beans ([13], reviewed in [162]).

Seeds, roots and leaves of the castor bean plant, called "erandah" in Sanskrit, have been used in Ayurveda as well as in Siddha medicine of the Tamil Nadu in South India and Sri Lanka for different purposes, including as a decoction for internal use or a poultice for external application, often as a polyherbal formulation. The castor bean tree has been credited to possess analgesic, anti-inflammatory and antipyretic properties, thus offering relief for every type of arthritic pain, swelling and feverishness. It was also used in digestive disorders and as an anthelmintic, anti-tumour, anti-convulsive, anti-bacterial and anti-diabetic agent. Castor bean oil was known to favour hair growth and to have aphrodisiac, cathartic and labour-inducing actions (reviewed in [113]).

Among the plants of the Ayurveda tradition that were present in preparations due to their therapeutic actions, Momordica charantia L. (bitter melon) has been used for thousands of years. The fruit, also identified as karela, is also harvested as food. Every part of the plant possesses pharmacological action, including the seeds, roots, leaves and particularly the unripe fruits, which have anti-mutagenic activity, are able to scavenge superoxide and hydroxyl radicals and are known for their anti-diabetic activity (reviewed in [93]). In ancient times, the juice of the fruit was used as a remedy in cases of snake poisoning. It was also considered effective for the alleviation of pain in the joints and against chronic fever. It was deemed to be helpful in cases of jaundice and disorders of the liver or the digestive system for its diuretic, laxative and anti-helminthic actions. The juice of the leaves and fruits was applied externally to cure chronic disorders of the skin as well as in the treatment of burns, boils and eruptions. The ingestion of the plant may help control excessive sugar in the urine and blood, and its medicinal chemistry has been revised together with the biochemical properties and mechanisms of its beneficial effects in the treatment of diabetes (reviewed in [94,95]). A variety of herbal remedies were prescribed in Ayurvedic, Siddha and Unani medicine for the treatment of diabetes, including asparagus, bitter melon, castor bean, colocynth and jequirity. A decoction of cockscomb seeds has been reported to possess anti-diabetic properties, according to traditional Indian medicine [40].

Abelmoschus esculentus L. (okra) is cultivated in Africa, America, Asia and Southern Europe for its nutritional value. According to Ayurvedic medicine, the consumption of okra has been suggested for the management of various diseases such as gastric ulcer, diabetes and cancer [5]. Trichosanthes cucumerina L. (snake gourd) is an edible vegetable that is grown in Asia, Australia and the Pacific Islands, known since ancient times, and is also used in Ayurvedic, Siddha and Unani traditional medicines as a drug with anti-inflammatory, anti-cancer, anti-diabetic, anti-ovulatory, larvicidal, and hepato- and gastro-protective activity (reviewed in [133]). The ingestion of the fresh juice of the winter melon, also called kundur fruit, was suggested in Ayurveda for the treatment of diabetes, nervous diseases, peptic ulcers and urinary disorders, whereas in Korean traditional medicine, it was used to cure dropsy, liver and intestinal diseases (reviewed in [30]). In addition, a number of other RIP-expressing plants listed in Table 1 have been recognized as having anti-diabetic properties in Ayurvedic, Siddha and Unani medicine, although the mechanism of anti-diabetic activity has been attributed to plant components other than RIPs [54]. 
Ayurvedic medicine is still popular in India, and this care system is spreading around the world, not only as an alternative disease treatment but also as a philosophy for health maintenance.

\section{Unani Medicine}

The Greek and Roman knowledge about the therapeutic use of plants was absorbed by the Arabs, in particular Avicenna (980-1037 AD), who was the author of the "Canon of Medicine", and was the starting point of Unani medicine, which was practiced in the Indian medieval Muslim culture. Thus, the crude traditional drugs of the ancient Egyptians became the foundation of the empirical materia medica until the 18th century. For instance, in Unani medicine, barley has been prescribed for many diseases and to soothe the bowels. In addition, barley water was considered effective in the treatment of fever.

During the Islamic Golden Age, Arab physicians became aware of the medical knowledge of India and China and established a connection between Oriental and Western medicines of ancient origin, as suggested by the fact that some of the plants that are described in Islamic medical treatises show similar clinical indications in both traditional Chinese and Unani medicine (reviewed in [46]). In addition, in Unani medicine, many herbal remedies were common to Ayurveda, in particular those reported for the treatment of diabetes.

Unani medicine persisted in all areas of Islamic culture along the old Silk Road starting from Turkey, the Middle East, Persia and Pakistan, as well as in North Africa, although with some differences due to the variety of the local flora and folk traditions.

In various traditional medicines of the Middle East Unani area, including Jordan [50], Iran (reviewed in [51]) and Pakistan [22], the fruits, roots and seeds of the colocynth have been prescribed to cure diabetes and parasitic, infectious and inflammatory diseases but also as a diuretic, cathartic and abortive drug. In Jordanian traditional medicine, beet leaves and roots have been used to obtain relief against acute and chronic inflammation [34]. Rice has been identified as a remedy against diarrhoea in the traditional medicine of Palestine [100].

In traditional Iranian medicine, several edible fruits have been recommended for the management of peptic ulcers such as pumpkin and rice for their anti-acid and anti-oxidant activities (reviewed in [63]). The use of dwarf elder has been recommended as an anti-fungal remedy against mycotic skin infections [119] and as a painkiller to treat a variety of bone and joint pathologies [120]. In addition, the aqueous extract of castor bean leaves has been mentioned to alleviate the pain induced by chronic knee osteoarthritis [118].

In Pakistan traditional medicine, some uncommon uses are reported for balsam as a wound healer and peas as an anti-spermatogenesis agent [89]. Amaranthus viridis L. (amarant) has been used in Indian Ayurdeda and Pakistan traditional medicine as a whole-plant decoction to stop dysentery, the root juice has been used to treat inflammation, and the leaves were recommended for snake bites and scorpion stings [22]. Chenopodium album L. (lambsquarters) has been prescribed in Indian Ayurvedic and Pakistan Unani medicine under the name of bathu as a diuretic, laxative, sedative, and hepatoprotective drug, as well as in veterinary medicine for its anthelmintic properties [45]. The same use against animal parasites was traditionally diffuse in Ethiopia [44]. Poultices of leaves or seeds of castor bean were administered for external use to cure gout and rheumatism as well as to treat wounds, boils and sores, while the juice of the leaves was given orally to treat liver disease [22].

In Turkish folk medicine, beet leaves were recommended for the treatment of diabetes [32]; bottle gourd was used to treat headache by wrapping the head with its leaves, whereas the oil obtained from the ripe fruits of bitter melon, macerated in olive oil warmed by the sun, was combined with honey and used for the prevention and healing of gastric ulcers [80]. A decoction of dwarf elder flowers was used against cough, while an external application of a leaves decoction was considered effective in the treatment of snakebites and as a roots poultice to alleviate rheumatism pain. A decoction of elderberry flowers was suggested for a variety of pulmonary diseases including bronchitis and asthma. A decoction of mistletoe fruits and leaves was recommended for the treatment of many different 
affections [97]. This traditional medicine is still practiced among Islamic populations and many of the herbal remedies above listed are still recommended in Oriental and Middle East countries, as well as in Africa.

\section{European Folk Medicine}

The folk medicine of different European cultures was based on a mix of ancient knowledge and magic superstitions, primarily related to local plants that were growing in the temperate climate around the Mediterranean Sea or in North and East Europe. These old traditions were passed down orally for centuries, and no ancient written text is available.

According to Norse mythology, a mistletoe arrow caused the first winter by killing Odin's son Balder, who was "the bright, the shining one" and who was also knowledgeable in healing herbs. The use of mistletoe extracts persisted in European folk medicine through the ages and is still part of alternative medicine for the complementary treatment of cancer, especially in the German-speaking area, under the name Iscador ([141], reviewed in [142]).

On the Mediterranean coasts of Europe, either castor bean leaves or the juice from the leaves was applied on the breast in the puerperium as galactogogue (reviewed in [112]). The ability of promoting lactation by castor bean may be interpreted as a result of the irritating action that can be induced by subtoxic amounts of ricin, but can be also caused by other undetermined substances present in castor bean leaves. Elderberry has been traditionally used as a decoction of flowers and leaves to treat cough and asthma, or for external application in the case of pimples and for eye inflammation, as well as an ointment that was prepared with bark and pith in olive oil to alleviate burns. Wheat preparations were applied on skin lesions as a bran decoction that was mixed with vinegar to cure sprains, as flour in olive oil in the case of whitlows, mixed with crushed snails for burns and wounds and as a whole germ in honey to cicatrize burns. A decoction of mistletoe was placed on chilblains to favour healing [124].

In Eastern Europe folk medicine, a decoction of elderberry flowers was recommended as a diuretic or for colds and influenza, as an antiseptic and an anti-catarrhal to reduce inflammation and treat fever. Many RIP-expressing plants have been used for their disinfectant and anti-inflammatory functions. Although the role of RIPs in the medicinal actions of these plants has not been ascertained, it is possible to hypothesize a contribution of RIPs for their antiviral activity, as well as because of macrophage sensitivity to their cytotoxicity (reviewed in [157]). The aerial part of mistletoe was mixed with garlic and was used as an ethanolic extract for internal use for sedative and diuretic properties in the case of nervous tachycardia and insomnia, arteriosclerosis and hypertension [127].

In Northern Europe, the elderberry has been used to prepare beverages either as a fresh berry juice or as a dried berry tea for the cathartic, diuretic and diaphoretic properties in the treatment of constipation, upper respiratory tract infections, back pain, headache and toothache (reviewed in [125]).

The herbal remedies of traditional folk medicine have become part of the natural products in the field of complementary and alternative medicine that today are utilized by a large number of European citizens.

\section{African Folk Medicine}

In Africa, treatment of diseases is mainly based on crude indigenous herbal products that are produced by adherence to the directions of traditional healers and have never been codified in medical treatises, but are solely based on oral tradition. Folk medicine has become enriched over the centuries and has been influenced by cultures, religions and migrations. Islamic medicine had an important influence, particularly in North Africa. This medicine is mainly based on preparations from the plant kingdom. The drugs are prepared by water extraction of the components from the whole plant or from single parts, either alone or more frequently in combination. The extracts are prepared in the form of decoctions, concoctions and infusions, for oral consumption, enemas and inhalations, or as ointments or pastes for topical applications. Among the plants that are used by African healers to prepare pharmacological remedies, there are some from which RIPs have been purified. 
The Passifloraceae Adenia digitata (Harv.) Engl. (modecca flower) and Adenia volkensii Harms (kilyambiti plant) are poisonous plants that are largely present in South and tropical Africa, respectively. Modecca flower roots, rubbed into swelling or applied warm, are used in the treatment of knee swelling, while a decoction is taken to treat skin ailments, leprosy, ulcers and swollen legs. A roasted rootstock powder of kilyambiti plant is used to treat coughs, colds, and pneumonia and is taken with milk to treat stomach ache and swelling. A leaf decoction is taken orally to treat bronchitis, coughs, and fever or is used as a purgative enema [20].

Balsam and bitter melon are used for the cure of various diseases and preparations containing every part of the plants, including fruits, leaves, roots, seeds and leaf juice or decoction are utilized both for internal and external treatment [88].

Castor bean crushed fruits or oil are used alone or in combination with the ashes or powder of various other plants for local application or is rubbed into the scarifications that are made on the ailing part of the body for the treatment of different ocular, cutaneous or articular affections [109]. The roots are chewed or boiled and drunk to induce uterine contraction and abortion [82].

Colocynth is used in Tunisia, Morocco and other Islamic Mediterranean countries. Different parts of the plant, especially fruits and seeds, are often used. Common preparations use fresh, warmed or dried plant material (often ground), as well as extracts that are used mostly in a liquid form. Extracts are prepared either in water or in aqueous mixtures that contain more lipophilic compounds (hot milk extractions, water/olive oil at various ratios) at a temperature that ranges from tepid to boiling. Ground plant material can be mixed with honey for ingestion or for a topical gynaecological application or with other plants for poultices. The main indications are for the treatment of diabetes, inflammatory disorders, dermatological problems and various type of infections. For centuries, the colocynth fruits have also been used for cancer treatment [53,56,57].

Various parts of Jatropa curcas L. (purging nut) are used in traditional African medicine to cure different diseases, from simple fevers to serious infectious diseases. Seeds are employed as purgative; leaves are taken to cure fever and rheumatism. The latex and stems are utilized as anti-inflammatory agents and are used to treat various infections and infestations. Root decoctions are consumed for gingivitis and toothache, eczema and skin parasites [73]. The stem bark is used for the treatment of infertility and miscarriage [74].

Jequirity roots are used as sedatives and anticonvulsants in Amerindian and African medicine. Extracts from the roots have a moderate sedative effect. Leaves that are given in association with palm oil are taken to treat convulsions [7].

The stalks of Manihot esculenta Crantz (tapioca), cut into 2-3-cm pieces and inserted into the vagina, are used as an abortifacient to increase the uterine contractive activity and for the expulsion of the foetus [82].

Mistletoe, given as the whole plant or milk infusion, is used to provide relief for painful menstruation, asthma, bronchitis, stomach ailments and to reduce tumour swellings [106]. Mistletoe leaves, given as a juice or as decoction, find application in the therapy of hypertension [143].

Pokeweed fruits, roots and leaves are traditionally used to treat wound, fibroid growth, swelling and rheumatism [106]. Phytolacca dodecandra L'Hér. (African soapberry) finds application in the treatment of malaria, rabies, sore throat, rheumatic pain and jaundice as well as for various skin disorders and diseases depending on common pathogens [108].

Ximenia americana L. (sea lemon) is included in the therapy of many different diseases. The most frequently used part of the plant is the root, but the leaves, bark, fruits, stem and seeds can also be used. The plant is given as decoction, powder or after maceration. The leaves are also used as aqueous crude extract. The main indications are for the treatment of burns and wounds, infections, inflammation, pain and gynaecological disorders. Sea lemon extracts are also used as a tonic, a laxative and as an antidote for food poisoning and snake/scorpion bites [149-151]. 
In Africa, the majority of the population still uses traditional medical systems for most or all of their health care. This occurs in particular in rural areas where modern health care facilities are scarce or difficult to reach; thus, most people still depend on folk medicine.

\section{American Folk Medicine}

More than $50 \%$ of the species that belong to the plant kingdom are present in Central and South America. Over 3000 of these plants are used in folk medicine for the treatment of various ailments.

Bitter melon is widely present in the Caribbean area, and it is administered as a leaf decoction or fruit juice for the treatment of diabetes. The leaf decoction is also used for the treatment of high blood pressure and various type of infections. Leaf baths are used for rheumatism therapy (reviewed in [18]).

Corn silk tea is consumed by Mexicans for oliguria and dysmenorrhea treatment, husk tea for amenorrhea, and seeds are used for flu, dysentery, obesity, as an antioxidant, and for hypertension (reviewed in [18]).

Cucurbita maxima Duchesne (autumn squash) and pumpkin seeds are used as a folk remedy by several South American populations to expel intestinal worms and to treat urinary ailments, irritable bladder and benign prostatic hyperplasia [62]. In the Caribbean, pumpkin, as a flower or fruit decoction, is taken for measles and small pox, and as leaf poultice, is applied to sprains (reviewed in [18]).

Hura crepitans L. (sandbox tree) latex is used by Amazonian people on ailing teeth to cause them to fall out painlessly and without bleeding. Other uses are as an antidote for snakebites, an emetic, a purgative and as a drug to cure rheumatism, elephantiasis and leprosy [72].

Jequirity leaves are administered in the Caribbean for fevers, cough, cold and consumption; castor bean leaf poultice is used for stomach aches, erysipelas, flu, and inflammation of the womb. In Brazil, castor bean oil is used for wound healing, burns, hair loss, purgative, and as an anthelmintic (reviewed in $[18,19])$.

Mirabilis jalapa L. (four o'clock flower) leaves, as a decoction or an infusion, are extensively used by many South American inhabitants for treatment of diarrhoea and inflammatory and painful diseases; by Mexican people, it is also employed as a laxative [85].

Purging nut latex is applied by Caribbean people to external wounds to provide significant cicatrizing activity. The leaves are given in different manners: a leaf bath is used for rash and sprains, leaf poultices for sores and pains and leaf decoctions for heat, diarrhoea and fever. In Peru, the plant is also known for its anti-leishmanial use ([75,76], reviewed in [18]).

Sea lemon bark, fruits and roots are used in Brazil to treat a series of disease, including diabetes [19].

Tapioca leaf juice, orally administered, is used in Nicaragua for the treatment of abdominal pain, as an anti-pyretic, for diarrhoea, aches and pains. In Papua New Guinea, baths with tapioca are advised for treatment of skin blemishes. In Peru, as poultice, it is used to treat wounds. In Colombia, it is also used in human adults as vermifuge [84].

In Central and Southern Americas, medicinal plants are part of the heritage of pre-Columbian cultures. To date, they often remain the first choice for consultation and treatment in these countries.

\section{Modern Medicinal Use of Plant Producing Ribosome-Inactivating Proteins}

Only in a few cases, the pharmacological effect of RIP-expressing plant was due to the presence of RIP whereas most of the effects can be attributed to other components. For example, the laxative action of castor bean, still exploited today, is due to the oily part of the seeds, which is devoid of ricin toxin. However, the purgative and anthelmintic actions attributed in various traditional medicines to many RIP-producing plant could be correlated with the irritative effect caused to intestine by the administration of RIPs, as reported in toxicological studies (reviewed in [163]). 
In the case of both the abortive and antiviral effects of various Cucurbitaceae and other RIP-expressing plants, these medicinal activities have to be attributed to the presence of RIPs, as reviewed in $[164,165]$, respectively.

In particular, trichosanthin is a type 1 RIP from Chinese snake gourd belonging to the Cucurbitaceae family that has been used in traditional Chinese medicine as abortifacient and is still used in Chinese clinics for inducing midterm abortion. Trichosanthin produces follicular atresia in mouse and causes the embryo fails to develop by eliciting death of syncytiotrophoblasts of placental villi in fertilized animals (reviewed in [137]). The mechanism has been related to its uptake by, and high toxicity to, placental trophoblast cells, that also justify its application in the treatment of choriocarcinoma [166].

Momordica Anti-HIV Protein (MAP30), $\alpha$ - and $\beta$-momorcharins are type 1 RIPs from bitter melon that have been used in the folk medicine of various countries. These RIPs have been studied for their broad anti-viral activities and are considered potential therapeutic agents in HSV and HIV infections. MAP30 is non-toxic to normal cells, while it is active against infection and replication of both HSV and HIV. Moreover, MAP30 in combination with other antiviral drugs improves the efficacy of anti-AIDS therapy, by inhibiting HIV replication in acutely and chronically infected cells (reviewed in [167]).

Many medicinal plants have been claimed to possess anti-diabetic activity and are still used today for this reason in almost all the Oriental countries. Amongst these plants, the most studied is Momordica charantia L. and the active principles found in its fruit juice. However, its hypoglicemic activity, which has been observed in various animal experimentations and some clinical trials, is mainly due to an insulin-like protein unrelated to RIPs (reviewed in [95]).

In other cases, it is not yet clear whether the therapeutic activity that is ascribed to some plants is due to their ability to produce RIPs. A typical case is that of mistletoe and viscumin toxin, which is contained in the Iscador preparations that are marketed to fight cancer as an alternative and complementary medicine [141]. The anti-tumour activity of mistletoe preparation was evaluated through an overview of 23 clinical studies showing considerable heterogeneity of the trials and variable outcomes. Thus, properly designed further investigations are required to validate the efficacy of mistletoe as anti-cancer drug (reviewed in [142]). The anti-proliferative role of the toxic type 2 RIP present in mistletoe was not ascertained in these trials, however it cannot be excluded. Sometimes, great influence has been attributed to the growth conditions of the medicinal plant. Representative of this impact is the relevance of the plant on which mistletoe is a parasite on its pharmacologic properties (reviewed in [168]).

In addition, teas, liquid extracts, and capsules of dried flowers and berries of the European elderberry tree are currently suggested by integrative medicine to cure colds, constipation, fevers, flu and sinus infections, but no relation has been established with the RIP lectin contained in elderberry [169]. In vitro studies indicated anti-oxidant, anti-viral and anti-proliferative effects of elderberry fruit preparations. The aqueous elderberry extract showed promising results in the treatment of viral influenza infection of chimpanzees. An anti-viral and anti-inflammatory action has been suggested in humans, but need further support by more rigorous clinical trials. The pharmacological role of type 2 RIPs contained in these preparations has not been clarified, although their antiviral activity is known (reviewed in [125]).

The use of pumpkin as a remedy against swelling was known since the classic age. Indeed, its anti-inflammatory and anti-androgen activities may justify the modern application of pumpkin in the management of patients who are affected by benign prostatic hyperplasia (reviewed in [64]). However, no evidence is available that these effects may be related to the presence of a RIP.

Some RIP-expressing herbal remedies such as the different varieties of ginseng are recommended by alternative, complementary and integrative medicine for the presence of various components other than RIP.

A very new method to take advantage of the therapeutic effect of RIPs has been recently described. In a murine xenograft model, the gene of the type 1 RIP trichosanthin was delivered by a viral vector to 
human hepatocellular carcinoma tumour via intra-tumour injection, resulting in a significant inhibition of tumour growth [170].

\section{Conclusions}

Since the earliest times, humankind sought among the available herbs not only those that were edible for sustenance but also those that were suitable as remedies for diseases. The knowledge about the medicinal properties of plants was passed down orally long before being fixed in written texts, and only in recent times it has been subjected to a scientific validation to isolate the active components, check the toxicity, verify the effectiveness and understand the mechanism of action.

Folk medicine has always been based on the empirical wisdom of traditional healers. Not only it was, in the past, the unique resource against diseases, but it still represents the sole weapon available to fight illness for a large portion of the population in many parts of the world. Moreover, the need for new medicinal products addresses many studies towards the rich source of ethnobotany to discover pharmacologically useful compounds.

In the Oriental countries, local folk medicine continues to be preferred over Western drugs in many cases because of the fidelity to a traditional life style. The Chinese National Ministry of Science and Technology supports multicenter randomized controlled studies carried out to evaluate the results of the clinical trials with traditional Chinese medicine. This traditional medicine is now recognized worldwide as effective in treating various diseases, including cancer, when used in conjunction with Western medicine, being able to reduce toxicity and side effects induced by chemotherapy and radiotherapy ([171], reviewed in [172]).

The interest in medicinal products of plant origin is increasing in the Western world because they are considered more "natural" and thus less toxic, or even because they are linked to a philosophy of life. This trend justifies the increased popularity and spread of Chinese and Ayurvedic medicine and homeopathy as well as of integrative medicine all over the world. The reason why many RIP-containing plants are reported in the pharmacopoeia of traditional medicine in large part is due to their toxicity. It is no coincidence that the word pharmaceutical derives from the Greek "pharmakon", which means poison. Indeed, some of the required effects necessitate of a strong action, as in the case of purgative, abortifacient and anti-cancer drugs. The fact that some plants have been used in many countries, like for instance the castor bean, may depend on various causes, in primis the diffusion of a species in geographical areas with similar climate conditions, then the circulation of the traditional medicine in zones with economic and cultural exchanges. Considerable influence may have also had the written codification of the knowledge in texts that have been handed down over the centuries.

Medicinal effects, such as the anti-phlogistic, antalgic and anti-pyretic actions, are often attributed in traditional prescriptions to herbs that contain RIPs. Taking into account the high cytotoxicity of RIPs to macrophagic cells (reviewed in [173]), the presence of a RIP could contribute to the above activities by reducing the macrophagic response to pathogens, which is in many cases responsible of producing inflammatory cytokines. In addition, very often RIP-containing plants have been used in the treatment of various skin affections. Besides the anti-phlogistic effect, the presence of RIP in medicinal preparations for external use could have a disinfectant action and so promote healing of the lesions. However, the exact role of RIPs in herbal remedies remains unclear because in most cases, the traditional prescriptions consist of a mixture of different plants.

Today, the most promising prospects for the therapeutic use of plants that produce RIPs are related to the synthesis of conjugates, consisting of a purified RIP linked to a carrier, which should allow the specific binding to and the endocytosis of the resulting synthetic protein into the target cell to be deleted, such as cancer cells (reviewed in $[157,174]$ ).

This perspective was already envisaged by Ehrlich, who was dreaming of an ideal therapeutic agent made of a haptomer and an effectomer, that is a carrier able to specifically choose its target and a component with toxic properties able to kill the targeted cell. The discovery of monoclonal antibodies [175] provided highly specific haptomers. As far as the toxic component, the A chain of 
type 2 RIPs and the type 1 RIPs may represent the perfect effectomer, because they have a low toxicity unless being delivered inside the cell by a carrier. Thus, the so-called "immunotoxins", obtained by linking a monoclonal antibody to a RIP, somewhat allow to realize the "magic bullet" idea of Ehrlich.

Acknowledgments: This study was supported by the University of Bologna with funds for selected research topics and by Pallotti's Legacy for Cancer Research.

Author Contributions: L.P., M.B., and M.G.B. wrote the paper; M.G.B., and S.M. collected the literature; A.B. revised the paper.

Conflicts of Interest: The authors declare no conflict of interest.

\section{References}

1. Stirpe, F. Ribosome-inactivating proteins: from toxins to useful proteins. Toxicon 2013, 67, 12-16. [CrossRef] [PubMed]

2. Messing, J.; Thöle, C.; Niehues, M.; Shevtsova, A.; Glocker, E.; Borén, T.; Hensel, A. Antiadhesive properties of Abelmoschus esculentus (Okra) immature fruit extract against Helicobacter pylori adhesion. PLoS ONE 2014, 9, e84836. [CrossRef] [PubMed]

3. Sami, R.; Lianzhou, J.; Yang, L.; Ma, Y.; Jing, J. Evaluation of fatty acid and amino acid compositions in Okra (Abelmoschus esculentus) grown in different geographical locations. BioMed Res. Int. 2013, 2013, 574283. [CrossRef] [PubMed]

4. Kumar, K.; Sharma, Y.P.; Manhas, R.K.; Bhatia, H. Ethnomedicinal plants of Shankaracharya Hill, Srinagar, J\&K, India. J. Ethnopharmacol. 2015, 170, 255-274. [PubMed]

5. Sabitha, V.; Ramachandran, S.; Naveen, K.R.; Panneerselvam, K. Antidiabetic and antihyperlipidemic potential of Abelmoschus esculentus (L.) Moench. in streptozotocin-induced diabetic rats. J. Pharm. Bioallied Sci. 2011, 3, 397-402. [PubMed]

6. Sivasankari, B.; Anandharaj, M.; Gunasekaran, P. An ethnobotanical study of indigenous knowledge on medicinal plants used by the village peoples of Thoppampatti, Dindigul district, Tamilnadu, India. J. Ethnopharmacol. 2014, 153, 408-423. [CrossRef] [PubMed]

7. Stafford, G.I.; Pedersen, M.E.; van Staden, J.; Jäger, A.K. Review on plants with CNS-effects used in traditional South African medicine against mental diseases. J. Ethnopharmacol. 2008, 119, 513-537. [CrossRef] [PubMed]

8. Madikizela, B.; Ndhlala, A.R.; Finnie, J.F.; van Staden, J. Antimycobacterial, anti-inflammatory and genotoxicity evaluation of plants used for the treatment of tuberculosis and related symptoms in South Africa. J. Ethnopharmacol. 2014, 153, 386-391. [CrossRef] [PubMed]

9. Gul, M.Z.; Ahmad, F.; Kondapi, A.K.; Qureshi, I.A.; Ghazi, I.A. Antioxidant and antiproliferative activities of Abrus precatorius leaf extracts-An in vitro study. BMC Complement. Altern. Med. 2013, 13, 53. [CrossRef] [PubMed]

10. Mølgaard, P.; Nielsen, S.B.; Rasmussen, D.E.; Drummond, R.B.; Makaza, N.; Andreassen, J. Anthelmintic screening of Zimbabwean plants traditionally used against schistosomiasis. J. Ethnopharmacol. 2001, 74, 257-264. [CrossRef]

11. Van Wyk, B.E. A review of commercially important African medicinal plants. J. Ethnopharmacol. 2015, 176, 118-134. [CrossRef] [PubMed]

12. Moshi, M.J.; Kagashe, G.A.; Mbwambo, Z.H. Plants used to treat epilepsy by Tanzanian traditional healers. J. Ethnopharmacol. 2005, 97, 327-336. [CrossRef] [PubMed]

13. Garaniya, N.; Bapodra, A. Ethno botanical and Phytophrmacological potential of Abrus precatorius L.: A review. Asian Pac. J. Trop. Biomed. 2014, 4, S27-S34. [CrossRef] [PubMed]

14. Rao, P.K.; Hasan, S.S.; Bhellum, B.L.; Manhas, R.K. Ethnomedicinal plants of Kathua district, J\&K, India. J. Ethnopharmacol. 2015, 171, 12-27. [PubMed]

15. Barve, K.H.; Ojha, N. Effective detoxification of Abrus precatorius Linn. seeds by Shodhana. J. Ayurveda Integr. Med. 2013, 4, 82-85. [CrossRef] [PubMed]

16. Bhatia, H.; Pal Sharma, Y.; Manhas, R.K.; Kumar, K. Traditional phytoremedies for the treatment of menstrual disorders in district Udhampur, J\&K, India. J. Ethnopharmacol. 2015, 160, 202-210. [PubMed] 
17. De Boer, H.J.; Cotingting, C. Medicinal plants for women's healthcare in southeast Asia: A meta-analysis of their traditional use, chemical constituents, and pharmacology. J. Ethnopharmacol. 2014, 151, 747-767. [CrossRef] [PubMed]

18. Wong, W. Some folk medicinal plants from Trinidad. Econ. Bot. 1976, 30, 103-142. [CrossRef]

19. De Carvalho Nilo Bitu, V.; de Carvalho Nilo Bitu, V.; Matias, E.F.; de Lima, W.P.; da Costa Portelo, A.; Coutinho, H.D.; de Menezes, I.R. Ethnopharmacological study of plants sold for therapeutic purposes in public markets in Northeast Brazil. J. Ethnopharmacol. 2015, 172, 265-272. [CrossRef] [PubMed]

20. Quattrocchi, U. CRC World Dictionary of Medicinal and Poisonous Plants: Common Names, Scientific Names, Eponyms, Synonyms, and Etymology; Routledge: Abingdon-on-Thames, UK, 2012.

21. Osbaldeston, T.A.; Wood, R.P.A. Dioscorides, De Materia Medica. A New Indexed Version in Modern English; Ibidis Press: Johannesburg, South Africa, 2000.

22. Bibi, S.; Sultana, J.; Sultana, H.; Malik, R.N. Ethnobotanical uses of medicinal plants in the highlands of Soan Valley, Salt Range, Pakistan. J. Ethnopharmacol. 2014, 155, 352-361. [CrossRef] [PubMed]

23. Li, W.L.; Zheng, H.C.; Bukuru, J.; de Kimpe, N. Natural medicines used in the traditional Chinese medical system for therapy of diabetes mellitus. J. Ethnopharmacol. 2004, 92, 1-21. [CrossRef] [PubMed]

24. Li, F.; He, X.; Niu, W.; Feng, Y.; Bian, J.; Xiao, H. Acute and sub-chronic toxicity study of the ethanol extract from leaves of Aralia elata in rats. J. Ethnopharmacol. 2015, 175, 499-508. [CrossRef] [PubMed]

25. Li, F.; He, X.; Niu, W.; Feng, Y.; Bian, J.; Kuang, H.; Xiao, H. Sub-chronic safety evaluation of the ethanol extract of Aralia elata leaves in Beagle dogs. Regul. Toxicol. Pharmacol. 2016, 79, 1-11. [CrossRef] [PubMed]

26. Shikov, A.N.; Pozharitskaya, O.N.; Makarov, V.G.; Wagner, H.; Verpoorte, R.; Heinrich, M. Medicinal plants of the Russian Pharmacopoeia; their history and applications. J. Ethnopharmacol. 2014, 154, 481-536. [CrossRef] [PubMed]

27. Chung, Y.S.; Choi, Y.H.; Lee, S.J.; Choi, S.A.; Lee, J.H.; Kim, H.; Hong, E.K. Water extract of Aralia elata prevents cataractogenesis in vitro and in vivo. J. Ethnopharmacol. 2005, 101, 49-54. [CrossRef] [PubMed]

28. Yang, S.-Z. The Divine Farmer's Materia Medica: A Translation of the Shen Nong Ben Cao Jing, 1st ed.; Blue Poppy Press, Inc.: Boulder, CO, USA, 1998.

29. Shaw, P.C.; Chan, W.L.; Yeung, H.W.; Ng, T.B. Minireview: Trichosanthin-A protein with multiple pharmacological properties. Life Sci. 1994, 55, 253-262. [CrossRef]

30. Zaini, N.A.M.; Anwar, F.; Abdul Hamid, A.; Saari, N. Kundur (Benincasa hispida (Thunb.) Cogn.): A potential source for valuable nutrients and functional foods. Food Res. Int. 2011, 44, 2368-2376. [CrossRef]

31. Huang, H.Y.; Huang, J.J.; Tso, T.K.; Tsai, Y.C.; Chang, C.K. Antioxidant and angiotension-converting enzyme inhibition capacities of various parts of Benincasa hispida (wax gourd). Nahrung 2004, 48, 230-233. [CrossRef] [PubMed]

32. Bolkent, S.; Yanardağ, R.; Tabakoğlu-Oğuz, A.; Ozsoy-Saçan, O. Effects of chard (Beta vulgaris L. var. Cicla) extract on pancreatic B cells in streptozotocin-diabetic rats: A morphological and biochemical study. J. Ethnopharmacol. 2000, 73, 251-259. [CrossRef]

33. Güler, B.; Kümüştekin, G.; Uğurlu, E. Contribution to the traditional uses of medicinal plants of Turgutlu (Manisa-Turkey). J. Ethnopharmacol. 2015, 176, 102-108. [CrossRef] [PubMed]

34. Atta, A.H.; Alkofahi, A. Anti-nociceptive and anti-inflammatory effects of some Jordanian medicinal plant extracts. J. Ethnopharmacol. 1998, 60, 117-124. [CrossRef]

35. Aliotta, G.; Piomelli, D.; Pollio, A.; Touwaide, A. Le Piante Medicinali del "Corpus Hippocraticum"; Guerini e Associati: Milano, Italy, 2003.

36. Totelin, L.M.V. Hippocratic Recipes: Oral and Written Transmission of Pharmacological Knowledge in Fifth-and Fourth-Century Greece; Brill: Leiden, The Netherlands; Boston, MA, USA, 2009.

37. Ebers, G. Papyros Ebers: Das Hermetische Buch über die Arzneimittel der Alten Äegypter; Hinrichs, J.C., Ed.; Wilhelm Engelmann: Leipzig, Germany, 1875.

38. Carpenter, S.; Rigaud, M.; Barile, M.; Priest, T.J.; Perez, L.; Ferguson, J.B. An Interlinear Transliteration and English Translation of Portions of the Ebers Papyrus Possibly Having to do with Diabetes Mellitus; Bard College: Annandale-on-Hudson, NY, USA, 1998.

39. Von Kleine, C.H. The Medical Features of the Papyrus Ebers; American Medical Association: Chicago, IL, USA, 1905.

40. Vetrichelvan, T.; Jegadeesan, M.; Devi, B.A. Anti-diabetic activity of alcoholic extract of Celosia argentea Linn. seeds in rats. Biol. Pharm. Bull. 2002, 25, 526-528. [CrossRef] [PubMed] 
41. Priya, K.S.; Arumugam, G.; Rathinam, B.; Wells, A.; Babu, M. Celosia argentea Linn. Leaf extract improves wound healing in a rat burn wound model. Wound Repair Regen. 2004, 12, 618-625. [CrossRef] [PubMed]

42. Bakar, D.A.; Ahmed, B.A.; Taha, R.M. In vitro Callus Induction and Plant Regeneration of Celosia argentea-An Important Medicinal Plant. Braz. Arch. Biol. Technol. 2014, 57, 860-866. [CrossRef]

43. Wiart, C.; Mogana, S.; Khalifah, S.; Mahan, M.; Ismail, S.; Buckle, M.; Narayana, A.K.; Sulaiman, M. Antimicrobial screening of plants used for traditional medicine in the state of Perak, Peninsular Malaysia. Fitoterapia 2004, 75, 68-73. [CrossRef] [PubMed]

44. Peachey, L.E.; Pinchbeck, G.L.; Matthews, J.B.; Burden, F.A.; Mulugeta, G.; Scantlebury, C.E.; Hodgkinson, J.E. An evidence-based approach to the evaluation of ethnoveterinary medicines against strongyle nematodes of equids. Vet. Parasitol. 2015, 210, 40-52. [CrossRef] [PubMed]

45. Jabbar, A.; Zaman, M.A.; Iqbal, Z.; Yaseen, M.; Shamim, A. Anthelmintic activity of Chenopodium album (L.) and Caesalpinia crista (L.) against trichostrongylid nematodes of sheep. J. Ethnopharmacol. 2007, 114, 86-91. [CrossRef] [PubMed]

46. Heydari, M.; Hashempur, M.H.; Ayati, M.H.; Quintern, D.; Nimrouzi, M.; Mosavat, S.H. The use of Chinese herbal drugs in Islamic medicine. J. Integr. Med. 2015, 13, 363-367. [CrossRef]

47. Shahabi, S.; Jorsaraei, S.G.; Moghadamnia, A.A.; Zabihi, E.; Aghajanpour, S.M.; Mousavi Kani, S.N.; Pourbagher, R.; Hosseini, S.A.; Esmaili, M.; Yoonesi, A.A.; et al. Central effects of camphor on GnRH and sexual hormones in male rat. Int. J. Mol. Cell. Med. 2012, 1, 191-196. [PubMed]

48. Lee, H.J.; Hyun, E.A.; Yoon, W.J.; Kim, B.H.; Rhee, M.H.; Kang, H.K.; Cho, J.Y.; Yoo, E.S. In vitro anti-inflammatory and anti-oxidative effects of Cinnamomum camphora extracts. J. Ethnopharmacol. 2006, 103, 208-216. [CrossRef] [PubMed]

49. Buru, A.S.; Pichika, M.R.; Neela, V.; Mohandas, K. In vitro antibacterial effects of Cinnamomum extracts on common bacteria found in wound infections with emphasis on methicillin-resistant Staphylococcus aureus. J. Ethnopharmacol. 2014, 153, 587-595. [CrossRef] [PubMed]

50. Aburjai, T.; Hudaib, M.; Tayyem, R.; Yousef, M.; Qishawi, M. Ethnopharmacological survey of medicinal herbs in Jordan, the Ajloun Heights region. J. Ethnopharmacol. 2007, 110, 294-304. [CrossRef] [PubMed]

51. Rahimi, R.; Amin, G.; Ardekani, M.R. A review on Citrullus colocynthis Schrad.: From traditional Iranian medicine to modern phytotherapy. J. Altern. Complement. Med. 2012, 18, 551-554. [CrossRef] [PubMed]

52. Barghamdi, B.; Ghorat, F.; Asadollahi, K.; Sayehmiri, K.; Peyghambari, R.; Abangah, G. Therapeutic effects of Citrullus colocynthis fruit in patients with type II diabetes: A clinical trial study. J. Pharm. Bioallied Sci. 2016, 8, 130-134. [PubMed]

53. Hussain, A.I.; Rathore, H.A.; Sattar, M.Z.; Chatha, S.A.; Sarker, S.D.; Gilani, A.H. Citrullus colocynthis (L.) Schrad (bitter apple fruit): A review of its phytochemistry, pharmacology, traditional uses and nutritional potential. J. Ethnopharmacol. 2014, 155, 54-66. [CrossRef] [PubMed]

54. Marwat, S.K.; Rehman, F.; Khan, E.A.; Khakwani, A.A.; Ullah, I.; Khan, K.U.; Khan, I.U. Useful ethnophytomedicinal recipes of angiosperms used against diabetes in South East Asian Countries (India, Pakistan \& Sri Lanka). Pak. J. Pharm. Sci. 2014, 27, 1333-1358. [PubMed]

55. Mehta, A.; Srivastva, G.; Kachhwaha, S.; Sharma, M.; Kothari, S.L. Antimycobacterial activity of Citrullus colocynthis (L.) Schrad. against drug sensitive and drug resistant Mycobacterium tuberculosis and MOTT clinical isolates. J. Ethnopharmacol. 2013, 149, 195-200. [CrossRef] [PubMed]

56. Marzouk, B.; Marzouk, Z.; Haloui, E.; Fenina, N.; Bouraoui, A.; Aouni, M. Screening of analgesic and anti-inflammatory activities of Citrullus colocynthis from southern Tunisia. J. Ethnopharmacol. 2010, 128, 15-19. [CrossRef] [PubMed]

57. Daoudi, A.; Aarab, L.; Abdel-Sattar, E. Screening of immunomodulatory activity of total and protein extracts of some Moroccan medicinal plants. Toxicol. Ind. Health 2013, 29, 245-253. [CrossRef] [PubMed]

58. Tahraoui, A.; El-Hilaly, J.; Israili, Z.H.; Lyoussi, B. Ethnopharmacological survey of plants used in the traditional treatment of hypertension and diabetes in south-eastern Morocco (Errachidia province). J. Ethnopharmacol. 2007, 110, 105-117. [CrossRef] [PubMed]

59. Manoharan, S.; Kavitha, K.; Senthil, N.; Renju, G.L. Evaluation of anticarcinogenic effects of Clerodendron inerme on 7,12-dimethylbenz(a) anthracene-induced hamster buccal pouch carcinogenesis. Singap. Med. J. 2006, 47, 1038-1043. 
60. Huang, W.J.; Lee, H.J.; Chen, H.L.; Fan, P.C.; Ku, Y.L.; Chiou, L.C. Hispidulin, a constituent of Clerodendrum inerme that remitted motor tics, alleviated methamphetamine-induced hyperlocomotion without motor impairment in mice. J. Ethnopharmacol. 2015, 166, 18-22. [CrossRef] [PubMed]

61. Hu, J.; Gao, W.Y.; Ma, L.; Man, S.L.; Huang, L.Q.; Liu, C.X. Activation of M3 muscarinic receptor and Ca ${ }^{2}$ influx by crude fraction from Crotonis Fructus in isolated rabbit jejunum. J. Ethnopharmacol. 2012, 139, 136-141. [CrossRef] [PubMed]

62. Lans, C. Ethnomedicines used in Trinidad and Tobago for reproductive problems. J. Ethnobiol. Ethnomed. 2007, 3, 13. [CrossRef] [PubMed]

63. Farzaei, M.H.; Shams-Ardekani, M.R.; Abbasabadi, Z.; Rahimi, R. Scientific evaluation of edible fruits and spices used for the treatment of peptic ulcer in traditional Iranian medicine. ISRN Gastroenterol. 2013, 2013, 136932. [CrossRef] [PubMed]

64. Damiano, R.; Cai, T.; Fornara, P.; Franzese, C.A.; Leonardi, R.; Mirone, V. The role of Cucurbita pepo in the management of patients affected by lower urinary tract symptoms due to benign prostatic hyperplasia: A narrative review. Arch. Ital. Urol. Androl. 2016, 88, 136-143. [CrossRef] [PubMed]

65. Cai, H.; Liang, Q.; Ge, G. Gypenoside Attenuates $\beta$ Amyloid-Induced Inflammation in N9 Microglial Cells via SOCS1 Signaling. Neural Plast. 2016, 2016, 6362707. [PubMed]

66. Lokman, E.F.; Gu, H.F.; Wan Mohamud, W.N.; Östenson, C.G. Evaluation of Antidiabetic Effects of the Traditional Medicinal Plant Gynostemma pentaphyllum and the Possible Mechanisms of Insulin Release. Evid. Based Complement. Altern. Med. 2015, 2015, 120572. [CrossRef] [PubMed]

67. Xing, S.F.; Jang, M.; Wang, Y.R.; Piao, X.L. A new dammarane-type saponin from Gynostemma pentaphyllum induces apoptosis in A549 human lung carcinoma cells. Bioorg. Med. Chem. Lett. 2016, 26, 1754-1759. [CrossRef] [PubMed]

68. Huyen, V.T.; Phan, D.V.; Thang, P.; Hoa, N.K.; Ostenson, C.G. Gynostemma pentaphyllum Tea Improves Insulin Sensitivity in Type 2 Diabetic Patients. J. Nutr. Metab. 2013, 2013, 765383. [CrossRef] [PubMed]

69. Megalli, S.; Davies, N.M.; Roufogalis, B.D. Anti-hyperlipidemic and hypoglycemic effects of Gynostemma pentaphyllum in the Zucker fatty rat. J. Pharm. Pharm. Sci. 2006, 9, 281-291. [PubMed]

70. Huang, Q.F.; Zhang, S.J.; Zheng, L.; Liao, M.; He, M.; Huang, R.; Zhuo, L.; Lin, X. Protective effect of isoorientin-2"-O- $\alpha$-L-arabinopyranosyl isolated from Gypsophila elegans on alcohol induced hepatic fibrosis in rats. Food Chem. Toxicol. 2012, 50, 1992-2001. [CrossRef] [PubMed]

71. Gul, S.; Ahmed, S.; Kifli, N.; Uddin, Q.T.; Batool Tahir, N.; Hussain, A.; Jaafar, H.Z.; Moga, M.; Zia-Ul-Haq, M. Multiple pathways are responsible for anti-inflammatory and cardiovascular activities of Hordeum vulgare L. J. Transl. Med. 2014, 12, 316. [CrossRef] [PubMed]

72. Duke's Phytochemical and Ethnobotanical Databases. Available online: https://phytochem.nal.usda. gov/phytochem/ethnoPlants/show /1693?qlookup=hura+crepitans\&offset=0\&max=20\&et= (accessed on 30 August 2016).

73. Aiyelaagbe, O.O.; Hamid, A.A.; Fattorusso, E.; Taglialatela-Scafati, O.; Schröder, H.C.; Müller, W.E. Cytotoxic Activity of Crude Extracts as well as of Pure Components from Jatropha Species, Plants Used Extensively in African Traditional Medicine. Evid. Based Complement. Altern. Med. 2011, 2011, 134954. [CrossRef] [PubMed]

74. Falodun, A.; Nworgu, Z.A.; Osayemwenre, E. Smooth muscle relaxant evaluation of Jatropha curcas Linn (Euphorbiaceae) and isolation of triterpenes. Niger. J. Physiol. Sci. 2011, 26, 133-137. [PubMed]

75. Lans, C.; Harper, T.; Georges, K.; Bridgewater, E. Medicinal and ethnoveterinary remedies of hunters in Trinidad. BMC Complement. Altern. Med. 2001, 1, 10. [CrossRef] [PubMed]

76. Odonne, G.; Berger, F.; Stien, D.; Grenand, P.; Bourdy, G. Treatment of leishmaniasis in the Oyapock basin (French Guiana): A K.A.P. survey and analysis of the evolution of phytotherapy knowledge amongst Wayãpi Indians. J. Ethnopharmacol. 2011, 137, 1228-1239. [CrossRef] [PubMed]

77. Verma, A.; Jaiswal, S. Bottle gourd (Lagenaria siceraria) juice poisoning. World J. Emerg. Med. 2015, 6, 308-309. [CrossRef] [PubMed]

78. Kumar, N.; Kale, R.K.; Tiku, A.B. Chemopreventive effect of Lagenaria siceraria in two stages DMBA plus croton oil induced skin papillomagenesis. Nutr. Cancer 2013, 65, 991-1001. [CrossRef] [PubMed]

79. Puri, R.; Sud, R.; Khaliq, A.; Kumar, M.; Jain, S. Gastrointestinal toxicity due to bitter bottle gourd (Lagenaria siceraria)—A report of 15 cases. Indian J. Gastroenterol. 2011, 30, 233-236. [CrossRef] [PubMed]

80. Gürdal, B.; Kültür, S. An ethnobotanical study of medicinal plants in Marmaris (Muğla, Turkey). J. Ethnopharmacol. 2013, 146, 113-126. [CrossRef] [PubMed] 
81. Ha, H.; Lim, H.S.; Lee, M.Y.; Shin, I.S.; Jeon, W.Y.; Kim, J.H.; Shin, H.K. Luffa cylindrica suppresses development of Dermatophagoides farinae-induced atopic dermatitis-like skin lesions in Nc/Nga mice. Pharm. Biol. 2015, 53, 555-562. [CrossRef] [PubMed]

82. Nikolajsen, T.; Nielsen, F.; Rasch, V.; Sørensen, P.H.; Ismail, F.; Kristiansen, U.; Jäger, A.K. Uterine contraction induced by Tanzanian plants used to induce abortion. J. Ethnopharmacol. 2011, 137, 921-925. [CrossRef] [PubMed]

83. Peter, E.L.; Rumisha, S.F.; Mashoto, K.O.; Malebo, H.M. Ethno-medicinal knowledge and plants traditionally used to treat anemia in Tanzania: A cross sectional survey. J. Ethnopharmacol. 2014, 154, 767-773. [CrossRef] [PubMed]

84. Adeyemi, O.O.; Yemitan, O.K.; Afolabi, L. Inhibition of chemically induced inflammation and pain by orally and topically administered leaf extract of Manihot esculenta Crantz in rodents. J. Ethnopharmacol. 2008, 119, 6-11. [CrossRef] [PubMed]

85. Poovendran, P.; Vidhya, N.; Murugan, S. Antimicrobial activity of Mirabilis jalapa and Dichrotachys cinerea against biofilm and extended spectrum of beta lactamase (ESBL) producing uropathogenic Escherichia coli. Afr. J. Microbiol. Res. 2011, 5, 3620-3623. [CrossRef]

86. Walker, C.I.; Trevisan, G.; Rossato, M.F.; Silva, C.R.; Pinheiro, F.V.; Franciscato, C.; Tatsch, E.; Moretto, M.B.; Silva, M.D.; Manfron, M.P.; et al. Antinociceptive effect of Mirabilis jalapa on acute and chronic pain models in mice. J. Ethnopharmacol. 2013, 149, 685-693. [CrossRef] [PubMed]

87. Nath, L.R.; Manjunath, K.P.; Savadi, R.V.; Akki, K.S. Anti-inflammatory activity of Mirabilis jalapa Linn. leaves. J. Basic Clin. Pharm. 2010, 1, 93-96. [PubMed]

88. Neuwinger, H.D. African Ethnobotany: Poisons and Drugs: Chemistry, Pharmacology, Toxicology; Chapman and Hall: Weinheim, Germany, 1996.

89. Ishtiaq, M.; Hanif, W.; Khan, M.A.; Ashraf, M.; Butt, A.M. An ethnomedicinal survey and documentation of important medicinal folklore food phytonims of flora of Samahni valley, (Azad Kashmir) Pakistan. Pak. J. Biol. Sci. 2007, 10, 2241-2256. [CrossRef] [PubMed]

90. Giovannini, P.; Howes, M.J.; Edwards, S.E. Medicinal plants used in the traditional management of diabetes and its sequelae in Central America: A review. J. Ethnopharmacol. 2016, 184, 58-71. [CrossRef] [PubMed]

91. Joseph, B.; Jini, D. Antidiabetic effects of Momordica charantia (bitter melon) and its medicinal potency. Asian Pac. J. Trop. Dis. 2013, 3, 93-102. [CrossRef]

92. Clement, Y.N.; Baksh-Comeau, Y.S.; Seaforth, C.E. An ethnobotanical survey of medicinal plants in Trinidad. J. Ethnobiol. Ethnomed. 2015, 11, 67. [CrossRef] [PubMed]

93. Scartezzini, P.; Speroni, E. Review on some plants of Indian traditional medicine with antioxidant activity. J. Ethnopharmacol. 2000, 71, 23-43. [CrossRef]

94. Raman, A.; Lau, C. Anti-diabetic properties and phytochemistry of Momordica charantia L. (Cucurbitaceae). Phytomedicine 1996, 2, 349-362. [CrossRef]

95. Singh, J.; Cumming, E.; Manoharan, G.; Kalasz, H.; Adeghate, E. Medicinal chemistry of the anti-diabetic effects of Momordica charantia: Active constituents and modes of actions. Open Med. Chem. J. 2011, 5, 70-77. [CrossRef] [PubMed]

96. Phitsanuprasātwēt (Phrayā.) Tumra Paetsart Sonkhrau Chabub Anurak-Textbooks of Thai Traditional Medicine; Sarm Charoen Panich: Bangkok, Thailand, 1992.

97. Kültür, S. Medicinal plants used in Kirklareli Province (Turkey). J. Ethnopharmacol. 2007, 111, 341-364. [CrossRef] [PubMed]

98. Dandawate, P.R.; Subramaniam, D.; Padhye, S.B.; Anant, S. Bitter melon: A panacea for inflammation and cancer. Chin. J. Nat. Med. 2016, 14, 81-100. [CrossRef]

99. Tsoi, A.Y.; Ng, T.B.; Fong, W.P. Immunomodulatory activity of a chymotrypsin inhibitor from Momordica cochinchinensis seeds. J. Pept. Sci. 2006, 12, 605-611. [CrossRef] [PubMed]

100. Jaradat, N.A.; Ayesh, O.I.; Anderson, C. Ethnopharmacological survey about medicinal plants utilized by herbalists and traditional practitioner healers for treatments of diarrhea in the West Bank/Palestine. J. Ethnopharmacol. 2016, 182, 57-66. [CrossRef] [PubMed]

101. Chusri, S.; Settharaksa, S.; Chokpaisarn, J.; Limsuwan, S.; Voravuthikunchai, S.P. Thai herbal formulas used for wound treatment: A study of their antibacterial potency, anti-inflammatory, antioxidant, and cytotoxicity effects. J. Altern. Complement. Med. 2013, 19, 671-676. [CrossRef] [PubMed]

102. Kiefer, D.; Pantuso, T. Panax ginseng. Am. Fam. Phys. 2003, 68, 1539-1542. 
103. Gillis, C.N. Panax ginseng pharmacology: A nitric oxide link? Biochem. Pharmacol. 1997, 54, 1-8. [CrossRef]

104. Yin, J.; Zhang, H.; Ye, J. Traditional Chinese medicine in treatment of metabolic syndrome. Endocr. Metab. Immune Disord. Drug Targets 2008, 8, 99-111. [CrossRef] [PubMed]

105. Attele, A.S.; Wu, J.A.; Yuan, C.S. Ginseng pharmacology: Multiple constituents and multiple actions. Biochem. Pharmacol. 1999, 58, 1685-1693. [CrossRef]

106. Iwalewa, E.O.; McGaw, L.J.; Naidoo, V.; Eloff, J.N. Inflammation: the foundation of diseases and disorders. A review of phytomedicines of South African origin used to treat pain and inflammatory conditions. Afr. J. Biotechnol. 2007, 6, 2868-2885.

107. Wei, F.; Singh, R.S.; Fueth, M.; Swarts, S.; Okunieff, P.; Derendorf, H. Development and validation of a HPLC-MS/MS method for the determination of phytolaccagenin in rat plasma and application to a pharmacokinetic study. J. Pharm. Biomed. Anal. 2015, 107, 82-88. [CrossRef] [PubMed]

108. Tadeg, H.; Mohammed, E.; Asres, K.; Gebre-Mariam, T. Antimicrobial activities of some selected traditional Ethiopian medicinal plants used in the treatment of skin disorders. J. Ethnopharmacol. 2005, 100, 168-175. [CrossRef] [PubMed]

109. Chifundera, K. Livestock diseases and the traditional medicine in the Bushi Area, Kivu Province, democratic Republic of Congo. Afr. Stud. Monogr. 1998, 19, 13-33.

110. Lewu, F.B.; Afolayan, A.J. Ethnomedicine in South Africa: The role of weedy species. Afr. J. Biotechnol. 2009, 8, 929-934.

111. Sreekeesoon, D.P.; Mahomoodally, M.F. Ethnopharmacological analysis of medicinal plants and animals used in the treatment and management of pain in Mauritius. J. Ethnopharmacol. 2014, 157, 181-200. [CrossRef] [PubMed]

112. Scarpa, A.; Guerci, A. Various uses of the castor oil plant (Ricinus communis L.). A review. J. Ethnopharmacol. 1982, 5, 117-37. [CrossRef]

113. Ladda, P.L.; Kamthane, R.B. Ricinus communis (castor): An overview. Int. J. Res. Pharmacol. Pharmacother. 2014, 3, 136-144.

114. Nath, S.; Dutta Choudhury, M.; Roychoudhury, S.; Talukdar, A.D.; Misro, M.M. Male contraceptive efficacy of Ricinus communis L. extract. J. Ethnopharmacol. 2013, 149, 328-334. [CrossRef] [PubMed]

115. Sharma, J.; Gairola, S.; Gaur, R.D.; Painuli, R.M.; Siddiqi, T.O. Ethnomedicinal plants used for treating epilepsy by indigenous communities of sub-Himalayan region of Uttarakhand, India. J. Ethnopharmacol. 2013, 150, 353-370. [CrossRef] [PubMed]

116. Sharma, J.; Gairola, S.; Sharma, Y.P.; Gaur, R.D. Ethnomedicinal plants used to treat skin diseases by Tharu community of district Udham Singh Nagar, Uttarakhand, India. J. Ethnopharmacol. 2014, 158, 140-206. [CrossRef] [PubMed]

117. Al-Tamimi, F.A.; Hegazi, A.E. A case of castor bean poisoning. Sultan Qaboos Univ. Med. J. 2008, 8, 83-87. [PubMed]

118. Ziaei, A.; Sahranavard, S.; Gharagozlou, M.J.; Faizi, M. Preliminary investigation of the effects of topical mixture of Lawsonia inermis L. and Ricinus communis L. leaves extract in treatment of osteoarthritis using MIA model in rats. Daru 2016, 24, 12. [CrossRef] [PubMed]

119. Asgarpanah, J.; Hashemi, S.J.; Hashemi, E.; Askari, K. In vitro antifungal activity of some traditional Persian medicinal plants on pathogenic fungi. Chin. J. Integr. Med. 2015. [CrossRef] [PubMed]

120. Jabbari, M.; Hashempur, M.H.; Razavi, S.Z.; Shahraki, H.R.; Kamalinejad, M.; Emtiazy, M. Efficacy and short-term safety of topical Dwarf Elder (Sambucus ebulus L.) versus diclofenac for knee osteoarthritis: A randomized, double-blind, active-controlled trial. J. Ethnopharmacol. 2016, 188, 80-86. [CrossRef] [PubMed]

121. Yeşilada, E.; Ustün, O.; Sezik, E.; Takaishi, Y.; Ono, Y.; Honda, G. Inhibitory effects of Turkish folk remedies on inflammatory cytokines: Interleukin-1alpha, interleukin-1beta and tumor necrosis factor alpha. J. Ethnopharmacol. 1997, 58, 59-73. [CrossRef]

122. Shokrzadeh, M.; Saravi Saeedi, S.S. The chemistry, pharmacology and clinical properties of Sambucus ebulus: A review. J. Med. Plants Res. 2010, 4, 95-103.

123. Tuzlaci, E.; Tolon, E. Turkish folk medicinal plants, part III: Sile (Istanbul). Fitoterapia 2000, 71, $673-685$. [CrossRef]

124. Guarrera, P.M. Traditional phytotherapy in Central Italy (Marche, Abruzzo, and Latium). Fitoterapia 2005, 76, 1-25. [CrossRef] [PubMed] 
125. Vlachojannis, J.E.; Cameron, M.; Chrubasik, S. A systematic review on the sambuci fructus effect and efficacy profiles. Phytother. Res. 2010, 24, 1-8. [CrossRef] [PubMed]

126. Zakay-Rones, Z.; Thom, E.; Wollan, T.; Wadstein, J. Randomized study of the efficacy and safety of oral elderberry extract in the treatment of influenza A and B virus infections. J. Int. Med. Res. 2004, 32, 132-140. [CrossRef] [PubMed]

127. Jarić, S.; Popović, Z.; Macukanović-Jocić, M.; Djurdjević, L.; Mijatović, M.; Karadzić, B.; Mitrović, M.; Pavlović, P. An ethnobotanical study on the usage of wild medicinal herbs from Kopaonik Mountain (Central Serbia). J. Ethnopharmacol. 2007, 111, 160-175. [CrossRef] [PubMed]

128. Sezik, E.; Yesilada, E.; Tabata, M.; Honda, G.; Takaishi, Y.; Fujita, T.; Tanaka, T.; Takeda, Y. Traditional medicine in Turkey VIII. Folk medicine in east Anatolia; Erzurum, Erzincan, Agri, Kars, Igdir provinces. Econ. Bot. 1997, 51, 195-211. [CrossRef]

129. Liu, C.; Dai, L.H.; Dou, D.Q.; Ma, L.Q.; Sun, Y.X. A natural food sweetener with anti-pancreatic cancer properties. Oncogenesis 2016, 5, e217. [CrossRef] [PubMed]

130. Li, C.; Lin, L.M.; Sui, F.; Wang, Z.M.; Huo, H.R.; Dai, L.; Jiang, T.L. Chemistry and pharmacology of Siraitia grosvenorii: A review. Chin. J. Nat. Med. 2014, 12, 89-102. [CrossRef]

131. Lu, F.; Liu, J.; Huang, Y.; Li, D. Simultaneous determination of six cucurbitane triterpene glycosides in Siraitia grosvenorii fruits using high performance liquid chromatography. Se Pu 2008, 26, 504-508. [PubMed]

132. Ma, L.; Song, J.; Shi, Y.; Wang, C.; Chen, B.; Xie, D.; Jia, X. Anti-hepatitis B virus activity of chickweed (Stellaria media (L.) Vill.) extracts in HepG2.2.15 cells. Molecules 2012, 17, 8633-8646. [CrossRef] [PubMed]

133. Sandhya, S.; Vinod, K.R.; Sekhar, J.C.; Aradhana, R.; Nath, V.S. An updated review on Tricosanthes cucumerina L. Int. J. Pharm. Sci. Rev. Res. 2010, 1, 56-60.

134. Arawwawala, M.; Thabrew, I.; Arambewela, L.; Handunnetti, S. Anti-inflammatory activity of Trichosanthes cucumerina Linn. in rats. J. Ethnopharmacol. 2010, 131, 538-543. [CrossRef] [PubMed]

135. Kar, A.; Choudhary, B.K.; Bandyopadhyay, N.G. Comparative evaluation of hypoglycaemic activity of some Indian medicinal plants in alloxan diabetic rats. J. Ethnopharmacol. 2003, 84, 105-108. [CrossRef]

136. Yeung, H.W.; Li, W.W. Beta-trichosanthin: A new abortifacient protein from the Chinese drug, wangua, Trichosanthes cucumeroides. Int. J. Pept. Protein Res. 1987, 29, 289-292. [CrossRef] [PubMed]

137. Sha, O.; Niu, J.; Ng, T.B.; Cho, E.Y.; Fu, X.; Jiang, W. Anti-tumor action of trichosanthin, a type 1 ribosome-inactivating protein, employed in traditional Chinese medicine: A mini review. Cancer Chemother. Pharmacol. 2013, 71, 1387-1393. [CrossRef] [PubMed]

138. Fei, X.; Hill, M.; Ma, X.; Teng, L.; Li, Q.; Stöckigt, J. Isolation of a putative ribosome inactivating protein from dried roots of Trichosanthes kirilowii used in Traditional Chinese Medicine. Planta Med. 2004, 70, 364-365. [PubMed]

139. Kim, S.R.; Seo, H.S.; Choi, H.S.; Cho, S.G.; Kim, Y.K.; Hong, E.H.; Shin, Y.C.; Ko, S.G. Trichosanthes kirilowii Ethanol Extract and Cucurbitacin D Inhibit Cell Growth and Induce Apoptosis through Inhibition of STAT3 Activity in Breast Cancer Cells. Evid. Based Complement. Altern. Med. 2013, 2013, 975350.

140. Gray, A.M.; Flatt, P.R. Insulin-secreting activity of the traditional antidiabetic plant Viscum album (mistletoe). J. Endocrinol. 1999, 160, 409-414. [CrossRef] [PubMed]

141. Ostermann, T.; Raak, C.; Büssing, A. Survival of cancer patients treated with mistletoe extract (Iscador): A systematic literature review. BMC Cancer 2009, 9, 451. [CrossRef] [PubMed]

142. Kienle, G.S.; Berrino, F.; Büssing, A.; Portalupi, E.; Rosenzweig, S.; Kiene, H. Mistletoe in cancer-A systematic review on controlled clinical trials. Eur. J. Med. Res. 2003, 8, 109-119. [PubMed]

143. Gbolade, A. Ethnobotanical study of plants used in treating hypertension in Edo State of Nigeria. J. Ethnopharmacol. 2012, 144, 1-10. [CrossRef] [PubMed]

144. Ladokun, O.; Ojezele, M.; Arojojoye, O. Comparative study on the effects of aqueous extracts of Viscum album (mistletoe) from three host plants on hematological parameters in albino rats. Afr. Health Sci. 2015, 15, 606-612. [PubMed]

145. Özdemir, E.; Alpınar, K. An ethnobotanical survey of medicinal plants in western part of central Taurus Mountains: Aladaglar (Nigde-Turkey). J. Ethnopharmacol. 2015, 166, 53-65. [CrossRef] [PubMed]

146. Orhan, N.; Hoçbaç, S.; Orhan, D.D.; Asian, M.; Ergun, F. Enzyme inhibitory and radical scavenging effects of some antidiabetic plants of Turkey. Iran. J. Basic Med. Sci. 2014, 17, 426-432. [PubMed]

147. Sargın, S.A.; Akçicek, E.; Selvi, S. An ethnobotanical study of medicinal plants used by the local people of Alaşehir (Manisa) in Turkey. J. Ethnopharmacol. 2013, 150, 860-874. [CrossRef] [PubMed] 
148. Avci, G.; Kupeli, E.; Eryavuz, A.; Yesilada, E.; Kucukkurt, I. Antihypercholesterolaemic and antioxidant activity assessment of some plants used as remedy in Turkish folk medicine. J. Ethnopharmacol. 2006, 107, 418-423. [CrossRef] [PubMed]

149. Le, N.H.; Malterud, K.E.; Diallo, D.; Paulsen, B.S.; Nergård, C.S.; Wangensteen, H. Bioactive polyphenols in Ximenia americana and the traditional use among Malian healers. J. Ethnopharmacol. 2012, 139, 858-862. [CrossRef] [PubMed]

150. Cheikhyoussef, A.; Shapi, M.; Matengu, K.; Mu Ashekele, H. Medicinal properties of Ximenia; Lessons from the traditional healers in Oshikoto region, Namibia. In Proceedings of the 1st National Research Symposium, Windhoek, Namibia, 15-17 September 2010.

151. Magassouba, F.B.; Diallo, A.; Kouyaté, M.; Mara, F.; Mara, O.; Bangoura, O.; Camara, A.; Traoré, S.; Diallo, A.K.; Zaoro, M.; et al. Ethnobotanical survey and antibacterial activity of some plants used in Guinean traditional medicine. J. Ethnopharmacol. 2007, 114, 44-53. [CrossRef] [PubMed]

152. Obón, C.; Rivera, D.; Alcaraz, F.; Attieh, L. Beverage and culture. "Zhourat", a multivariate analysis of the globalization of a herbal tea from the Middle East. Appetite 2014, 79, 1-10. [CrossRef] [PubMed]

153. Owoyele, B.V.; Negedu, M.N.; Olaniran, S.O.; Onasanwo, S.A.; Oguntoye, S.O.; Sanya, J.O.; Oyeleke, S.A.; Ibidapo, A.J.; Soladoye, A.O. Analgesic and anti-inflammatory effects of aqueous extract of Zea mays husk in male Wistar rats. J. Med. Food 2010, 13, 343-347. [CrossRef] [PubMed]

154. Lock, O.; Perez, E.; Villar, M.; Flores, D.; Rojas, R. Bioactive Compounds from Plants Used in Peruvian Traditional Medicine. Nat. Prod. Commun. 2016, 11, 315-337. [PubMed]

155. Leake, C.D. The Old Egyptian Medical Papyri; University of Kansas Press: Lawrence, KS, USA, 1952.

156. Barbieri, L.; Polito, L.; Bolognesi, A.; Ciani, M.; Pelosi, E.; Farini, V.; Jha, A.K.; Sharma, N.; Vivanco, J.M.; Chambery, A.; et al. Ribosome-inactivating proteins in edible plants and purification and characterization of a new ribosome-inactivating protein from Cucurbita moschata. Biochim. Biophys. Acta 2006, 1760, 783-792. [CrossRef] [PubMed]

157. Stirpe, F. Ribosome-inactivating proteins. Toxicon 2004, 44, 371-383. [CrossRef] [PubMed]

158. Newman, C.W.; Newman, R.K. A brief history of barley foods. Cereal Foods World 2006, 51, 4-7. [CrossRef]

159. Berns, A.D. The Bible and Natural Philosophy in Renaissance Italy. Jewish and Christian Physicians in Search of Truth; Cambridge University Press: Cambridge, UK, 2014.

160. Saito, H. Regulation of herbal medicines in Japan. Pharmacol. Res. 2000, 41, 515-519. [CrossRef] [PubMed]

161. Sharma, R.K.S. Charaka Samhita: English Commentary; Dash, V.B., Ed.; Chaukambha Sanskrit Series Office: Varanasi, India, 1977; Volume I-II.

162. Bhatia, M.; Siddiqui, N.A.; Gupta, S. Abrus precatorius (L.): An Evaluation of Traditional Herb. Indo Am. J. Pharm. Res. 2013, 3, 3295-3315.

163. Battelli, M.G. Cytotoxicity and toxicity to animals and humans of ribosome-inactivating proteins. Mini Rev. Med. Chem. 2004, 4, 513-521. [CrossRef] [PubMed]

164. Ng, T.B.; Chan, W.Y.; Yeung, H.W. Proteins with abortifacient, ribosome inactivating, immunomodulatory, antitumor and anti-AIDS activities from Cucurbitaceae plants. Gen. Pharmacol. 1992, 23, 579-590. [CrossRef]

165. Battelli, M.G.; Stirpe, F. Ribosome-Inactivating Proteins from Plants. In Antiviral Proteins in Higher Plants; Chessin, M., DeBorde, D., Zipf, A., Eds.; CRC Press: Boca Raton, FL, USA, 1995; pp. 39-64.

166. Battelli, M.G.; Montacuti, V.; Stirpe, F. High sensitivity of cultured human trophoblasts to ribosome-inactivating proteins. Exp. Cell Res. 1992, 201, 109-112. [CrossRef]

167. Puri, M.; Kaur, I.; Kanwar, R.K.; Gupta, R.C.; Chauhan, A.; Kanwar, J.R. Ribosome inactivating proteins (RIPs) from Momordica charantia for anti viral therapy. Curr. Mol. Med. 2009, 9, 1080-1094. [CrossRef] [PubMed]

168. Adesina, S.K.; Illoh, H.C.; Johnny, I.I.; Jacobs, I.E. African mistletoes (Loranthaceae); ethnopharmacology, chemistry and medicinal values: An update. Afr. J. Tradit. Complement. Altern. Med. 2013, 10, 161-170. [CrossRef] [PubMed]

169. Ulbricht, C.; Basch, E.; Cheung, L.; Goldberg, H.; Hammerness, P.; Isaac, R.; Khalsa, K.P.; Romm, A.; Rychlik, I.; Varghese, M.; et al. An evidence-based systematic review of elderberry and elderflower (Sambucus nigra) by the Natural Standard Research Collaboration. J. Diet. Suppl. 2014, 11, 80-120. [CrossRef] [PubMed] 
170. Zhang, Y.H.; Wang, Y.; Yusufali, A.H.; Ashby, F.; Zhang, D.; Yin, Z.F.; Aslanidi, G.V.; Srivastava, A.; Ling, C.Q.; Ling, C. Cytotoxic genes from traditional Chinese medicine inhibit tumor growth both in vitro and in vivo. J. Integr. Med. 2014, 12, 483-494. [CrossRef]

171. Zhai, X.F.; Chen, Z.; Li, B.; Shen, F.; Fan, J.; Zhou, W.P.; Yang, Y.K.; Xu, J.; Qin, X.; Li, L.Q.; et al. Traditional herbal medicine in preventing recurrence after resection of small hepatocellular carcinoma: A multicenter randomized controlled trial. J. Integr. Med. 2013, 11, 90-100. [CrossRef] [PubMed]

172. Ling, C.Q.; Yue, X.Q.; Ling, C. Three advantages of using traditional Chinese medicine to prevent and treat tumor. J. Integr. Med. 2014, 12, 331-335. [CrossRef]

173. Barbieri, L.; Battelli, M.G.; Stirpe, F. Ribosome-inactivating proteins from plants. Biochim. Biophys. Acta 1993, 1154, 237-282. [CrossRef]

174. Polito, L.; Djemil, A.; Bortolotti, M. Plant Toxin-Based Immunotoxins for Cancer Therapy: A Short Overview. Biomedicines 2016, 4, 12. [CrossRef]

175. Kohler, G.; Milstein, C. Continuous cultures of fused cells secreting antibody of predefined specificity. Nature 1975, 256, 495-497. [CrossRef] [PubMed]

(C) 2016 by the authors; licensee MDPI, Basel, Switzerland. This article is an open access article distributed under the terms and conditions of the Creative Commons Attribution (CC-BY) license (http:/ / creativecommons.org/licenses/by/4.0/). 